$$
\text { - } 1982
$$




\title{
Colonization and Pidginization on the Ubangi River
}

\author{
WILLLAM J. SAMARIN
}

The genesis of Sango, ${ }^{1}$ pidginized in the 19 th century, involved too many factors to allow it to fit neatly into any one of the numerous scenarios proposed for pidgins. One of these I disallowed soon after my first encounter with this language (Samarin 1955). Sango, I said, could not possibly be accounted for in the way Bloomfield (1933) did when he wrote about how pidgins came into existence. There was no evidence of anything like a plantation system where a dominated population tried but failed to arrive at native-like command of the dominant language. That was a possible explanation for pidgins based on European languages, but Sango was African.

That causal explanation did not disappear (witness, for example, Nida and Fehderau 1970 and Bouquiaux 1978: 21). And in the meantime, with the tremendous increase in speculation about pidginization, explanations have become more nuanced and linguistically more sophisticated. Nonetheless, because critical sociohistorical studies like those by Reinecke for Hawaiian Pidgin (1969) are still scarce, Sango fits no one's speculative history.

The present study is a sketch of principal aspects of Sango's history, with emphasis being placed on presenting the earliest attestations. While my methodology consists of determining the linguistic sources for words

* My research on the topic of this paper began around 1970 and has been pursued until the present on an occasional basis, with the exception of the academic year of 1979-1980, which was entirely devoted to this purpose. Support for this work has come from several sources: the University of Toronto (from both the International Studies Programme and the Humanities and Social Sciences Research Programme), the American Philosophical Society, the Social Sciences Research Council (USA), and the Social Sciences and Humanities Research Council of Canada. I am grateful not only to these organizations but also to all the individuals who have helped over the years. They are too many to name here, but I must single out Mahadev Apte, Charles Gilman, George Huttar, Peter Mühlhäusler, and Edgar C. Polomé, whose critical reading of an earlier version of this paper helped substantially in many ways. An abbreviated version of this work was presented at the Annual Meeting of the Linguistic Society of America, New York City, December 1981, with the title "Accounting for the origin of a Ubangian pidgin". 
attributed to one or another ethnic group or said (or implied) to be in general use on the Ubangi river in the 19th century, it relies on a critical use of all sources. Therefore linguistics and history are combined in the 'disciplining' of the data.

Sango, I claim, developed as a contact language within a very few years after Belgian and French presence was established in the Ubangi river basin. Some would say therefore that Sango was a product of colonization. The expression "product of colonization", however, obscures rather than clarifies the nature of the events to be described. It may suit our purposes in the end to typologize Sango's origin under this rubric, but not before we understand more of what actually happened. Given these views, the word "colonization" in the title is a bit of indulgence, justified by my desire to relate linguistic history to sociopolitical and ethnic history in central equatorial Africa.

Indeed, it is my intention in my research on Sango (as well as on Bangala) to contribute to the history of colonialism in central equatorial Africa. It does this, among other ways, by making explicit the linguistic aspects of that event: Implied, therefore, are not merely the languages that were used and how they were used but also who used what. My hypothesis about the development of Sango as a pidginized lingua franca must, of course, also have bearing on the general question of the origins of pidgins. In this paper, however, I do not refer directly to the already extensive literature on that subject.

\section{IOREIGNERS IN THE UBANGI BASIN}

The only foreigners in the Ubangi basin we need to concern ourselves with are the Belgians and the French and the Blacks in their service. 'Arab' traders were busy at the end of the 19th century in the Zande and Banda territory at the eastern end of the Ubangi river (de Dampierre 1967; Cordell 1977). (The term 'Arab' was applied by Whites in general to all the Muslim colonialists or traders, even those with African physical features.) In those relations Arabic (or possibly pidginized Chad Arabic) and indigenous vernaculars were used. In any case, speakers of indigenous Sango-related dialects do not seem to have been involved.

These dialects include those that have come to have names like Sango, Ngbandi, Mongwandi, Yakoma, and Dendi, all of which would appear to constitute a dialect cluster on the basis of, at least, contigual mutual intelligibility (see Lekens 1923 and 1952, with map by Mortier). Discussion of Pidgin Sango (henceforth PS or simply Sango) is made awkward by the fact that the vernacular is known by the same name (henceforth VS, applied indiscriminately to the whole dialect cluster unless 
otherwise specified). In the past, to maneuver discussion around this terminological problem and because the dialectal base of PS had not yet been determined, I arbitrarily assigned the name Ngbandi to the putative source of PS. (See the map on the last page of this article.)

Among the first Europeans to come to this eastern region, the only ones who need to be mentioned are Georg Schweinfurth, who discovered the Wele (Ouelle) river in $1870, P$. Potagos, who may have discovered the Mbomu (Mbomou) river in 1875, and W. Junker who stayed both at the zariba (armed camp) of one Ali-Kobbo near the Wele in 1883 and almost a year at Semio (Zemio), on the Mbomu. (The chronology is that of de Dampierre; his location of Ali-Kobbo is farther to the north of what my. sources suggest.) But these Whites were travellers and explorers, whose expeditions in any case did not, as far as we know, come into contact with VS.

Sango history starts not with the arrival of foreigners from the noth but from the south, and all of it up the Ubangi river. There were explorations by Belgians into the territory between the Congo and the Ubangi rivers. Alphonse Van Gele, for example, tried going up the Itimbiri river in July of 1887 , but was stopped by rapids and dense jungle. It was not until May 1890 that Milz was able to make his way up the eastern part of the État Indépendant du Congo (É.I.C. or Congo Free State) and establish a post at Djabir; but by that time, as we see below; Van Gèle was already established $90 \mathrm{~km}$. away at Yakoma and, as I believe, some variety of VS was in the process of pidginization.

No extant history is adequate for what we need in writing the history of PS. De Dampierre's (1967) is primarily ethnohistory, dealing with the Zande Kalck's (1974), based on his two-volume doctoral thesis (1970), while treating of some matters that concern us; is shallow and incomplete for our purposes. What we require is (a) an accurate linguistic and ethnic description of the populations along the Ubangi river and of their relationships with each other (my first contribution to which is Ms 1); (b) a chronology of the arrivals and movements of Whites in the period critical for the emergence of the pidgin; and (c) a description of the work force of the Whites, including the workers they brought with them and those they recruited in the region.

The chronology presented in the appendix only suggests the increasing intensity of the efforts by the Belgians and the French to occupy the territory, in keen and deadly-serious competition with each other. Duning the early part of this period the boundaries between their domains had not been staked out, and in the latter part, after the Belgians had withdrawn from north of the $4^{\circ}$, the French, were frantically trying to prevent the British from reoccupying the upper reaches of the Nile river. It is in this period that movement on the Ubangi river assumes great proportions (say, 
1896-1897), but by this time contact Sango seems to be in wide use along the Ubangi river. ${ }^{3}$

The introduction of the expression "contact Sango" into the discussion is deliberate, and its purpose is to postpone taking a position as to when (more or less exactly) PS can be said to exist. Conceptually that sentence is incomplete, for what is implied is "Pidgin Sango as a form of language all, or most, of us can agree is a pidgin." The problem, obviously, is that scholars are far from agreeing on what a pidgin is (see, e.g., Samarin 1971a and the papers in Valdman 1977). There is no need in this present study to take a position with respect to the stabilization of grammar in PS. In any case, I am here presenting all we know at the present about the "proto-history" of PS.

\section{RECOGNITION OF A UBANGIAN CONTACT LANGUAGE}

It was not until 1908 that there appeared anything like grammatical evidence for the existence of PS. This is Giraud's, based on personal experience in the few years preceding this date. In the following year was published the vocabulary of Sango by Brachiel, but he had been in the area since 1901 as an agent of the Société des Sultanats and director of the Sociéte 'La Kotto' in 1908. The next is the grammar and vocabulary of P. Calloc'h (1911). ${ }^{4}$ In these works we find features that have persisted to this day. (There are a few earlier word-lists. Although they do not provide direct attestation of a pidgin, they may be used as indirect evidence, for which see below.)

While the works just cited demonstrate the existence of pidginized Sango in the first decade of this century, they give no idea of the extent of its use. This we can gather from Roeykens (n.d.) who describes the earliest history of the teaching done by Capuchin missionaries in Banzyville around 1910-1911. He reports that these priests determined from the very start to use the maternal language of the children. It is not clear what this policy excluded: possibly the use of French or Flemish, but also perhaps of Bangala (BG), which had for many years been used by the Belgians as a lingua franca in the upper regions of their colony. For example, Thonner, writing of the year 1896 in the interior of the Congo Free State said (1899: 27): "Dans leurs rapports avec les noirs, les blancs se servent d'habitude des idiomes des nègres, le plus souvent de celui des Bangala. Dans le Haut-Congo, la langue française n'est pas même enseignée dans les missions."

It was merely by accident that one of their missionaries at Banzyville, P. De Boeck (as related in his account of 1940), discovered that the indigenous language was not what they had learned, being guided by the 
works of Brachiel and Calloc'h, but something like what was spoken to the south at Budjala, where Scheutist missionaries, particularly P.H. De Clercq, had been collecting linguistic data and translating religious material. Whereas it is sufficient to explain this error on the part of the Capuchins by claiming that the local Sango people (for this is what they were, according to Whites, although calling themselves Mbati) used that language which they expected Whites to use, it is also reasonable to assume that this case demonstrates the widespread knowledge of the pidginized language by these same people. I assume that at this time PS was fairly well stabilized, as revealed in the work of P. Calloc'h already cited. (I do not believe that the children all came to school already knowing the pidgin. Even in the 1950s and 1960s, PS was acquired by most children only when they went to school in the Central African Republic.

The earliest reference to a contact medium is that of Brunache, who was a member of Jean Dybowski's expedition in 1892. In a memoir of his colonial days he wrote: "Nos hommes avaient peu à peu réuni quelques mots à l'aide desquels ils avaient constitué une sorte de patois, qui leur permettait jusqu'ici de se faire facilement comprendre des indigènes" (1894: 206). But this is not by any means unequivocal evidence for pidginized Sango. In fact, what he is describing is a 'patois' based on what he calls Ndri, which is a Banda dialect. According to Dyé (1899: 445) the word Ndri applies to all the inland people who otherwise go by the names Langwasi, Bubu, Togbo, and Gobu, in opposition to the riverine peoples, known collectively as Wate (Ouaté). For the latter term see also below. Without a thorough reconstruction of the ethnography of this period, or even one limited to the Bandas, we cannot judge the accuracy of this statement.

The full context is required to understand Brunache's statement (1894: 205-206):

\begin{abstract}
Depuis la Kemo jusqu'ici [which is the right bank of the Vasako river], notre jeune Togbo, les petits N'dris, les deux femmes, se faisaient comprendre avec la plus grande facilité. C'est que l'idiome n'dri est employé à quelques rares exceptions près, depuis les N'gapoux jusque près de Bangui et de l'Oubangui, vers le $8^{\circ}$ lat. N. Les riverains de l'Oubangui, 'Sangos,' Banziris, Bondjios et Bouzerous, ne s'en servent pas habituellement, mais le parlent presque tous.
\end{abstract}

If this 'patois' was a pidginized Banda, it had a very short life. Some might want to argue, on the other hand, that it was related to one of the jargons spoken on the Ubangi even though not "habitually". (There are quite a few Banda words in PS, but we have not yet determined when they might have entered the language in its stabilized form. Most of these words may not have been absorbed until the 20th century, when the 
interior of the country was occupied with the help of indigenous militia, many of them Banda, and where Banda is the most widespread of languages.)

It would be wiser for us at this state of the analysis to list the possible interpretations of the observations just quoted: (a) The expatriate Black personnel in the Dybowski expedition were using local linguistic means for communicating with the indigenous population; (b) The Banda members of the expedition made themselves understood through their own or some other local language or ad hoc linguistic means; (c) There was a jargon, whatever its linguistic base might have been, that was available to those who more or less frequently came into contact with each other.

Indirect evidence coming from the year 1895 could apply to at least the preceding year if not earlier. In an inventory of word-lists available in July of that year occurs one for "la langue Wa ou Dendi (Ubangi)" (Congo Belge, SD 1958). ${ }^{5}$ What is significant about this record is that Dendi is one of the dialects of the Sango-Yakoma-Ngbandi dialect-cluster. This could, of course, be only a collection of words and phrases from the vernacular language, as we have for Yakoma (Girard 1901) and Mongwandi (Thonner 1899), where there is no suggestion of pidginization. Unfortunately, the Dendi word-list has not yet been recovered. It is quite likely that $\mathrm{Wa}$ as a name of the language is an error, possibly going back to some word or phrase like wate or wagigi, which referred to the riverine and inland "Sango" respectively; $w a$ is a morpheme that can be translated 'person' in VS.

What is nonetheless important is that this inventory is not simply of "divers dialectes indigènes" or "idiomes employés par les populations" among whom the Whites found themselves but rather languages which the Whites found most helpful all the way from the coast to the MbomuWele basins. The complete list is the following:

1. Vocabulaire pour la route des Caravanes de Matadi à Léopoldville

2. Vocabulaire de la langue Wa ou Dendi (Ubangi)

3. Vocabulaire Mombutu (zone de la Makua)

4. Vocabulaire Français-Kiswahili

5. Vocabulaire Kiswahili, Fiote, Kibangi-Irebu, Mongo et Bangala de Mr. le lieutenant Lemaire.

The first might refer to Fiote, that is, pidginized Kikongo, but it is more likely that the words were from several different languages - whatever might have been useful for the White traveler. Mombutu is probably to be identified with the ethnic name located in a few of the early maps, as in that of Johnston (1908, vol. 2), just east of the $28^{\circ}$ E. and just south of the sources of the Wele river, spelled Monbouttou and Mang-Battou by Reclus (1888, Vol. 13), therefore identified as what we now know as 
Mangbetu. Since the Wele was often identified as the Makua or WeleMakua in the earliest maps, this administrative zone must be of "la [rivière] Makua." This must have been an important language for the expeditions that were going up north in the 'Arab campaigns.' (Is it possible that there is some relation between this 'Mombutu' language and 'Moganzulu' for which St. Norbert missionaries in the Wele region provided a word list (see St. Norbert 1901 and Samarin 1975), along with one for BG? In any case, if Moganzulu was found nearer the Wele river, then it cannot be identified with the village I have cited in the map as Monganzulu.) The last item was published by Lemaire, of which there is record only of the second edition of 1897 , but it is cited in Lemaire (1894). Kibangi and Mongo are closely related indigenous languages of the Congo-Lulonga river basins. Bangala, whatever its source turns out to be, was by this time an established contact language.

My earliest attestation for what came to be known as Bangala (BG) is 1890, when the Baptist Missionary Society established work in August at Monsembi (on maps yariously Monsembe, Monzembê, Munsembi, Moussembe, Momhambe, Monhanbe), Writing of that time, Walter $\mathbf{H}$. Stapleton, one of the founders, said: "Reaching this place, we found it a town of 3,000 inhabitants, the people speaking a miserable patois of Kilolo and Kibangi"' (MH 1892: 226). John Weeks, the other cofounder, provides more in formation about this language:

On the main river there was a mixed language, commonly called among us the 'trade language'; by means of this lingua franca we were able to make ourselves understood at the various places at which we touched on our search for a new site, and it stood us in good stead during our carly days among the Monsembe people. There was a large èlement of Bobangi in it, some Kiswahili words; and a few Lower Congo [presumably pidginized Kikongo] words and phrases. This 'trade language' has now been supplanted by what is called the 'Bangala language,' which is a mixture of the languages alrcady mentioned, with a smattering of Bangala words thrown in (Weeks 1913: 48).

It appears that there was a time when the language we now call Sango was known as Dendi. For example; Baratier, who was a member of Marchand's expedition to the Nile around 1897 , has this to say about the language: "C'est le Dendi qui a dönné son nom à la langue qui se parle tout le long de l'Oubangui et qui est une sorte de volapuk" (p. 28). And Girard, writing about the Yakoma and Bugu, says, "les relations s'établissent entre toutes les tribus voisines dans le Haut-Oubanghi, grâce à un sabir special, le dendi" (1901: 85). According to Dyê (1899), Dendi and Sango were Belgian and French names respectively.

The next explicit reference to a contact language is that of $P$ Goblet, 
writing at the Mission Ste. Famille on 31 July 1896. After saying that the missionaries are learning the Langwasi language, believing it to be the most widespread, he declares: "Je ne parle pas de ce langage barbare de la rivière, qui fait que tu te comprends avec toutes les tributs riveraines. Ce n'est pas une langue, mais un volapuck quelconque" (Goblet, CSE V. 181.B, Cahier 4). ${ }^{6}$

In the next year, 1897 , this contact language goes by the name it has now. Bruel, district officer at the French post at Mobaye, writing to his mother, says, "La langue d'ici est le Sango corrompu, langue de commerce et qui sert aux relations avec les Blancs dans toute la rivière (Te) [meaning the Ubangi] de Bangui à Sémio" (ASOM, Bruel B2-17, 16 April 1897).

Two other statements from the year 1899 make it incontestable that there was a generally recognized contact language along the Ubangi river by the end of the century:

Chaque race [of the Ubangi territory] parle un idiome spécial, mais tous ces peuples communiquent entre eux, en employant une sorte de patois compris de tout le monde et que l'on appelle 'langue de rivière'; c'est de ce patois que les Européens et Sénégalais se servent pour entrer en relations avec les indigènes (Pourbaix and Plas 1899: 11).

Un patois commun sert de langue commerciale entre les diverses tribus de la rivière, et aussi pour les transactions avec les Européens. C'est le sango, ou dendi des Belges. Il est compris depuis Rafai, où a pénétré le patois arabe du Haut-Nil, jusqu'au confluent de l'Oubangui et du Congo (Dyé 1899: 445).

The evidence that has just been cited not only demonstrates the existence of a contact language, it also locates it as a riverine phenomenon and suggests its linguistic nature. It was called a 'patois,' a 'sabir,' a 'volapük,' a 'corrupted language', all revealing that the Whites put it in a different class from the other local languages and that they looked upon it with some disfavor. Clerc (1911: 303) may not share this attitude toward Sango, for the following statement seems to recognize it as a 'language": "La langue la plus répandu dans la région de l'Oubangui, et appelée pour cela 'langue de rivière' ou 'commerciale', est le Sango."

The earliest explicit statement about the 'mixed' nature of Sango, although this might be implied in the words sabir and volapük, is that of Siepi (1911: 48), who seems to believe that Sango is evidence of the emergence of a unified language for the whole area:

Les uns et les autres ont leur langage propre; mais l'on peut poser en règle générale qu'ils tendent tous à s'unifier dans leur langage et, à l'heure actuelle, tout Européen peut se faire comprendre sur l'Oubangui s'il parle le 'sango' dit de rivière, qui est un mélange de Sango, de Yakoma, de Banziri, etc. 
This idea of language unification can be related to others that characterized colonial ideology, which is a topic too far removed from our present one to deal with here. However, it is relevant to speculate that this idea, if it was generally held, would have led the Whites to encourage the use and spread of Sango.

\section{LINGUISTIC EVIDENCE FOR A CONTACT LANGUAGE}

Although there is good evidence for a contact idiom in the Ubangi basin in the 19th century, there is very little which gives us some idea of its nature. This study is based on what I have collected from a scrutiny of thousands of pages, published and unpublished, written by contemporaries of the period in question. As will be seen, some of the data come from words and phrases like those with which writers like to "spice up" their narratives. But in two instances there are word lists, in both cases erroneous in their attribution, but for that very reason important to the reconstruction of PS's history. It is not impossible that other word lists will come to light with future investigations in government archives and personal papers, such as those of Dr. Adolphe Cureau. However, there is no hope of getting anything comparable to the court proceedings and magisterial reports used in the study of Tok Pisin by Sankoff (1980). Exploration and colonization on the part of representatives of the French government here was military, ad hoc, and immediate!

\subsection{Onomastic evidence}

Onomastic evidence is provided in order to determine whether words from non-indigenous vernaculars were used of people or places in areas or contexts where they would not be expected. The evidence is scanty. There is, first of all, the name of the river Ba mingui outside of the ethnic Sango territory (about $8^{\circ} \mathrm{N}$ and just east of $16^{\circ}$ ) that flows into the Chari river. The fact that it occurs as two words on Maistre's map for his expedition of 1892 (Maistre 1893; also Julien 1902: 216) supports speculation that it might be the PS phrase '(it) bends (or twists) a lot' (or 'see much', with a verb different in tone and vowel length). I call it "Sango", but as a matter of fact only the verb $b a$ is VS 'to lean'; mingi is a Bantu word and certainly comes from BG. In PS today the grammatical phrase would have the subject marker with the verb, i.e, àbà 'it twists', but in VS the occurrence of this morpheme is realized in certain contexts only by its tone.

The earliest personal name from the nineteenth century may be Balao, which Dybowski (1893: 234) gave as the name of a Langwasi (Langouassi) 
chief he encountered on 14 November 1891. The phrase exists in Sango as a greeting: bàlà $\bar{o}$. If Dybowski's men used it in addressing the chief, Dybowski might have concluded that it was a personal name. But in matters such as this, one must be careful at making etymologies. There may indeed be such a name in Langwasi.

Lakoué is the name of one of the children that Mgr. Augouard had taken to Brazzaville from a 'Bondjo' village near Bangui in 1893, as far as I can make out, on his first visit to establish a mission at the bend of the Ubangi river. It is only in the daily journal of the Mission St. Paul near Bangui (1894, but I failed to note the specific date) that the child's name is cited, on the occasion when he is brought back home from Brazzaville. ${ }^{7}$ The name could very well be a locution in VS, in which $l a k$ k $k \dot{\varepsilon}$ means 'every day' (literally, 'sun all') and in PS 'every day, all the time, always'. It is perfectly appropriate, I should think, as a personal name in PS.

If the name was in the boy's native language and if it is in Sango, we would have to assume that there was near Bangui a village, if only a temporary one, of Sango from farther upriver, beyond Gbanziri territory. Notwithstanding what some have written (e.g. Kalck 1970), I am not convinced that these fisherpeople were established in this area. If I am correct, then the boy was given this name (and quite possibly a nickname) by other Blacks associated with the Whites.

A more reasonable explanation of this name is to attribute it to either Ngbaka (NGB), Gbanziri (GB), or Monzombo (MZ), in all of which something like NGB's la-kpe means 'sky'. The form dakoue which is given in d'Uzès (1894) for GB is explained by the fact that word-initial /1/ sometimes alternates with an imploded $/ \mathrm{d} /$. This etymology of Lakoue supports the argument for the place of NGB and GB in the local jargon.

In 1894 a Langwasi child of eleven years was bought from some Togbos by the missionaries at Ste. Famille (CSE Journal 1894-1897). His name also appears to be a Sango one: Gangou, probably Ngangu (since the Whites often did not perceive the initial prenasal consonants) 'strong, strength', a common name in the present century. But one must consider the fact that in the Monzombo language, coterritorial with the Banda dialects, ngángū means 'sugar cane', which, however, is less likely as a personal name than 'strong.'

The priests were early identified as Mokunzi Nzapa' chief (or important person) of sky'; cited for the year 1895, but possibly occurring much earlier (Goblet, CSE V.181.B, Cahier 3, Mission Ste. Famille, 15 July 1895, where the spelling is Mokonnzi Zapa). The first word is from Bangala, but the construction is typical of VS in not having the lexical marker of the possessive or qualificative relationship, namely, $t i$ or $t \varepsilon^{\prime}$. Although such a construction is possible in PS even today, there is a near categorical use of $t i$. 
Other names, but from a later period are the following: Fade 'right now, hurry up, soon', the name of a Garde Pavillon in 1904 (AN/SOMAix, 29 July 1905, 4(3)D12); BoyKété 'little (or junior) servant', whose proper name was Tomy (Challaye 1909: 127); Boy-Kota 'large (or senior) servant', a chief in the Fouroumbala Subdivision (AN/SOM-Aix, Rapport Mensuel, November 1910, 4(3)D17); Bangassou Kétté (that is, 'Bangassou Junior'), the son of Bangassou the Zande sultan; Krikri 'crooked, good-for-nothing, corrupt', one of the sons of the sultan Semio (AN/SOMAix, 15 September 1910, 4(3)D17). The glosses are not from the original sources but are my own.

The words fade, kete, kota, and krikri (also occurring as kirikiri) are found in VS and in the earliest forms of PS, but I am giving only the PS translations. The postposition of the attributives kota and kete (instead of, for example, kota boy) seems to be an innovation; I am not able to account for it in VS. In PS the usual position is before the noun, but there are phrases like these where the meaning differs from that with preposed attributive.

My familiarity with this culture area leads me to suspect that Ba mingi 'it twists a lot' derives from something that was actually said in a given moment of White presence and is not typical of VS river names. Fade 'hurry up'. on the other hand, might be a typical VS name. There was, for example, a "grand chef" by the name of Hounda (cf VS hüdà "to ask') who came to see Bruel at Mobaye, which is located in the very center of the VS area (ASOM, Bruel B2-48, Mobaye, 17 December 1897).

The study of personal and place names was undertaken to determine the extent to which VS was being used outside the geographical and social limits of ethnic Sangos. Although the data are very limited and for the most part problematic, there is some evidence nonetheless that VS had sufficient prominence among the personnel of the French that the latter took note of it. This is not enough, however, to lead me to believe in the predominance of a Sango jargon at the beginning of the $1890 \mathrm{~s}$.

\subsection{Syntactic and lexical evidence}

Here follow linguistic data for the period 1889-1899 which constitute further evidence for the presence of a contact language and its nature.

3.2.1. The earliest evidence for the sources of PS comes from a letter written on 17 November 1889 by Maurice Musy at Bangui, about five months after the French post, to which he had been assigned, was established here. He was subordinate to Uzac, the two being the only Whites on the station. The data consist of a list of translations of fifty French words plus the numbers from one to ten. Musy's comments about them are these: 
Je crois t'avoir déjà dit que je m'ćtais appliqué à apprendre la langue du pays. Actuellement je peux me faire comprendre pour les usages ordinaires de la vic. Je t'envoie ci-dessous un échantillon de ce baragouin.... Avec ces quelques mots usuels, j'achète tout seul, et je me fais à peu près comprendre. D'ici quelques mois, j'espère ne plus avoir besoin d'interprète (Musy 1890: 291, 292).

It is worth noting that Musy did not arrive on the west coast of Africa (at Loango) until 8 May 1889. He arrived at Brazzaville on 18 June and was still there on 20 July. On 23 August he is 'chef de poste', possibly because of Uzac's evacuation to Brazzaville for reasons of illness. Although he had been in equatorial Africa for only a short time, he was undoubtedly putting into practice what he had learned about managing with "exotic" languages in Indo-China.

Ngbaka could very well have been the language immediately around the site where the post was located. From speakers of NGB at Mongoumba I learned that one of the language's dialects was Mombangi, which actually is to be translated 'speech' (lit., 'mouth') of the Mbangi'. However, the people were referred to as the Bobangi.

The language Musy writes about is definitely Ngbaka (otherwise known as Ngbaka-Ma'bo). This is what one would expect from what we know about the distribution of ethnic groups at that time. However, his words are not all or purely NGB. Some of them are very similar if not identical to words in Gbanziri (an upriver member of the same dialect cluster), Monzombo, Banda, and even VS. This similarity is clearly explained by the close linguistic relationship between these languages. But a few words come from Bangala. In other words, the "langue du pays" was more than NGB but less than PS. Whatever the Blacks were using (of whom there were Senegalese, Bateke, 'Loango', and 'Pahouin', the latter known today as Fang), his own speech was a jargon.

Table 1 displays the probable sources of nine of Musy's words. These are studied because they are either not indigenous to NGB or because they have persisted into PS. The table illustrates not only the intrusion of BG into the idiom of Bangui at this early date but also the way cognate forms in other Ubangian languages must have reinforced the use of certain words in the jargon wherever it was used on the Ubangi river.

The citing of Bangala sources, while useful in the present context, leaves some matters ambiguous. For example, we do not consistently show what forms are found in what word lists, i.e. what words were widespread and which ones are found uniquely. While such information is important, the necessary comparisons of BG sources has yet to be done. Only in a few cases do we note unique occurrences in the data we now have.

Perhaps the most precious word in this collection is the one for 'gun' or 'rifle', because it is not a borrowing but a metaphoric creation based on 
Table 1. Etymological analysis of nine words used in Bangui in 1889 (Musy 1890). Abbreviations: NGB Ngbaka, GB Gbanziri, MZ Monzombo, VS Vernacular Sango, BD Banda, BG Bangala, PS Pidgin Sango. Sources of data: (1) Calloc'h 1911, (2) Samarin field work 1953, (3) Thonner $1899,(4)$ Compagnies 1895, (5) Lekens 1952, (6) Cotel 1900.

\begin{tabular}{|c|c|c|c|c|c|c|c|c|}
\hline & Musy & NGB & $\mathrm{GB}^{1}$ & $\mathrm{MZ}^{2}$ & $\mathrm{VS}^{5}$ & $\mathrm{BD}^{6}$ & $B G$ & PS \\
\hline gun & gombe & ngombe $^{1}$ & & & & & & ngòmbè \\
\hline egg & prangon & pala/para ngo' & pala & pa ngo & para & & & pārã \\
\hline water & gou & $\mathrm{ngo}^{1} / \mathrm{ngu}^{2}$ & ngu & ngo & $\mathrm{ngu}$ & ngu & & ngú \\
\hline banana & makondo & & & & & & likondo ${ }^{3}$ & fòndò \\
\hline chicken & koko & & & & & & nkoko ${ }^{3}$ & kóndò \\
\hline spear & li congo & & & & & & likongo $^{3}$ & lìkóngó \\
\hline
\end{tabular}


the indigenous word for 'lightning'. We do not know when the local population first encountered guns, possibly not until Grenfell and Van Gèle arrived. According to Musy, the natives around Bangui did not yet have rifles in 1889 .

Musy's word for 'fire' shows poor analysis, as with several of his entries: it consists of two words and means 'make a fire'. (But in my brief session with a speaker of NGB, I got something like sui wua for 'ashes' or 'embers'; and from a spcaker of MZ I got $z i$ wa for 'embers'. $)^{8}$ The form for 'banana' has the Bantu plural prefix $m a, l i$ is the singular. However, this distinction was not observed in early BG word lists and plural forms for some nouns were used for both singular and plural. In the case of the word for 'spear' Musy seems to have identified congo with the geographical name and $l i$ as a real noun! In the words for 'chicken' and 'oar' the noun prefix, which in this case is $n$, has been lost. For 'fish' see sec. 3.2.3. below.

\subsubsection{For the year 1891 there are three different attestations.}

na lolo coui 'quand le jour est mort' (Dybowski 1893: 214)

This is the earliest evidence of phrasal composition. Dybowski cites it to illustrate how the Gbanziri, whom they had recruited as canoers, tell time, but there is nothing of GB in this phrase. Working from the PS phrase, $n \dot{a} l a \dot{a} k w i$ 'and (or, at) sun die', we would naturally expect the words for 'sun' and 'die'. In the three closely related languages - GB, MZ, and $\mathrm{NGB}-k p i$ is the word for 'die', and something like bai occurs for 'sun' in both GB and NGB and bo or bao in MZ (Calloc'h 1911; Thomas 1963; Samarin field work).

The source of lolo must be some Banda dialect, for olo is given for 'sun' in Cotel (1907) and olo li for 'the sun sets' in Tisserant (1931). There is very good reason to believe that lolo is the result of a language learner's generalization of what appeared to be a characteristic reduplicative process in these languages. ${ }^{9}$ They have many words, as these from NGB for example, consisting of repeated syllables: gbigbi 'electric fish', gbjgbj 'lion'. Monosyllabic nouns, moreover, are repeated in a construction having the meaning 'the mentioned' or something of that kind: hớ nzònzó 'eat the head' (lit. 'eat head-head') as opposed to hớ nzò yìa 'the head of the elephant' (lit. 'eat head (of) elephant'). Verbs are also repeated in a "nominal" construction dependent on another verb: $m \bar{a}$ nố hàhă đớ 'I go to get the spear' (lit. 'I go get-get spear') (Thomas 1963: 204, 211, 216). In MZ a difference exists between áz $\bar{u} m \hat{o}$ 'she gave birth to twins' (lit. 'she bore twins') and $a g b \bar{o} z \dot{u} z \bar{u}$ 'she is giving birth' (lit. 'she is-in-process bear-bear').

There is an explicit reference to this feature by d'Uzès, who says that 
the Gbanziri have a "very special custom" of almost always doubling words that consist of only one syllable, such as pepe 'no' and fufu 'good', but also malengelenge 'necklace' (1894: 199). My speculation about the way repetition was conceived on the part of foreigners, whether Black or White, is supported by entries in Maistre's word lists (1895: 298) for both Ndri, A Banda dialect, and Mandjia, a Gbaya one: the word for 'water', for example, is given as goungou and lity respectively, whereas the word in each case is monosyllabic - something like ngu and $l i$. There was certainly something about the speech situation that evoked such repetitions. On the basis of my own field work in several Ubangian languages, I would say that we might be dealing with a language-area phenomenon.

The source of kwi is less clear than that of lolo. It could come from the simplification of $k p i$, which occurs for 'die' in GB, NGB, and MZ, as well as Nzakara and Zande (Santandrea 1965), and VS (although the sources, Calloc'h 1911 and Lekens 1958, write it $k p w i$ ), on the part of foreigners whose languages did not have the phoneme $/ \mathrm{kp} /$. On the other hand, it might be derived from the VS word kùt 'dark, somber', as in the sentence dà té mj kùi 'your house is dark' ('house of you dark'). In the earliest word list of PS the only word for 'die' is kwi. However, there is the word akwito 'dead, die' in Moganzulu, a Bantu language, to be reckoned with. (It appears that the final syllable is part of a suffix, because of these other words: kaseto 'see', waseto 'hear', masito 'dirt', kwaseto 'big', tasieto 'day'.) Its significance lies in the fact that it occurs in a missionary publication that includes Bangala, presumably because both of these languages were used by the St. Norbert missionaries in northeastern Congo (Samarin 1975). The significance of this possibility is not seen, however, until one understands the contribution that speakers of BG made to the genesis of Sango as a contact language.

Adding to the complexity of this phrase of three words is that $n a$ does not seem to come from either GB, NGB, or MZ, but from either VS or from $B G$, in which languages it is a preposition, certainly not a conjunction. (In BG $n a$ is also a concordial possessive.) The locution would therefore be a bit of jargon, ungrammatical at that, where a predication is used as a noun phrase with a preposition. I assume a verb phrase with 'sun' as a subject of the verb 'die'. What would have confused learners of VS, assuming that $k w i$ comes from that source, is that verbs sonetimes take the prefix $a$ - and sometimes not. Thus, in Ngbandi: zèke $\bar{a} k p \bar{i} t \bar{i} m b \bar{i}$ 'The dice died in my hand' and $z \dot{e} k \vec{e} t \dot{\epsilon} m b \vec{i} k p \vec{i}$ 'My dice died' (lit. 'dice/cowrie of me died') (Lekens 1958: 437a,b). Even today in PS there occurs nà lá àkwí ('at sun it-dies') and nả lá kwi for 'at evening, at sunset'. ('When the sun sets' would be rendered tòngà nà lá àkwi.)

Malengelenge 'necklace', which d'Uzès gives as a Gbanziri word, may, of course, come from some other language originally. Perhaps the Gban- 
ziri did use this word with this meaning; but if it came to them from another language, it may have been because they were speaking it: perhaps they were picking up words and phrases from the expatriate Blacks who were managing with a contact jargon. For this supposition we can provide as evidence Dybowski's statement that the Gbanziri (in 1891) were using the French banner, the sinza na fraça, that he first translates as "le drapeau des Français" and then "mot à mot: le pagne ou l'étoffe des Français" (1893: 367). This certainly is a BG locution, where na has the function of a possessive 'of' (although literary Lingala now has a concordial morpheme).

Lenge and lingi are cited by Calloc'h (1911) for NGB and GB respectively with the meaning 'bead(s)' ('perles'), but only as the second entry, the first of which is kisi or krisi (given as variants). This same word is cited by Cotel (1907) for BD with the variants kidji, kizi, and krisi. In the dictionary of Calloc'h, the adjectives for 'blue' and 'white' are added to lenge to specify the colors, and ngao is the word that has the meaning 'red beads'. But in Cotel's, color must be specified with ngao. In the Togbo dialect of $\mathrm{BD}$, according to Tisserant (1931), lenge means 'red beads' ('bapteroses'), and it has this meaning in Ngbandi as well (Lekens 1955). Today in PS lenge has only the meaning 'bead(s)' irrespective of color. To this list of languages that have cognates of the word must be added Azande, where linge means 'ring' (Gillaert, n.d.).

I deduce from these facts that something like kisi preceded the arrival of the Whites and that lenge was not at this early date already in the indigenous languages. Where the latter came from remains to be determined. It should be noted that lengelenge, with low tones, occurs in Djuka, one of the Afro-English creoles of Suriname, with the meaning 'dangling' (George Huttar, personal communication). If the Djuka and Ubangian word are related, we would have to assume an Atlantic coastal source, unless it could be demonstrated that the word was introduced via Arab (or Arabrelated) trading in the Ubangi area.

It should not be ignored, however, that the common word for 'bottle' in GB was something like malangi (Compagnies 1895$)^{10}$ or molangi (Wtterwulghe 1899). The latter cites molengi with this meaning in the Mangbetu language, which is coterritorial with Azande. Molangi (with mo as the noun-class singular prefix) is probably related to the source for the $B G$ word, since it occurs in Ntomba, which must be considered in reconstructing the origin of BG (Mamet 1960). I am not inclined to see in the word for 'bottle' the immediate etymon for lenge, and I would interpret d'Uzès' $m a$ as the Bantu plural prefix used with a word in reduplicated form.

Two other words from this year are cited in connection with the Dybowski mission. Both of them are Bangala, but they occurred in ethnic contexts where one would not expect them. 
(2) déko 'friend' (Dybowski 1894: 164); niama 'meat' (Brunache 1894: 112).

Deko (BG ndeko 'brother, sister, friend') was the word that was repeated while Dybowski went through the ritual of establishing a blood-brother relationship with a Bondjo while rubbing arms together.

Niama (BG 'animal, meat') is put in the mouths of the Ngapu people, a BD-speaking ethnic group, located, I estimate, about $100-125 \mathrm{~km}$ north of Bembe, through whose territory Paul Crampel had travelled in 1890. (One of their villages was Yabanda, for which see the map of Maistre 1893.) When Dybowski's troop arrives at a village, they find a prisoner all tied up and the people yelling niama, niama, and Brunache adds, "de la viande tel est le cri que l'on entend à tous moments", suggesting, of course, that the people wanted to kill and eat the prisoner. I doubt that the Ngapu actually used this word, or even a BD equivalent. Cannibalism was as much part of the foreign Black myth as it was of the White, and the incident was undoubtedly reported to the Whites as just another case of cannibalism.

$$
\text { la ço 'soleil là' (Fivé 1906: 7). }
$$

In PS today the phrase lá só ('sun this') means 'today, this day' and can be identified with the one cited by Fivé. The context of its use in 1891 is described by the author. He was negotiating with some chiefs concerning the recruitment of canoers to go further upstream. A meeting was called for at an hour when the sun would be at a certain height, indicated by pointing with a spear. Fivé says that it is the "indigène de l'Ubangi" who tells time in this way, suggesting that whenever you agreed on time in the Ubangi basin you followed this practice: point to the appropriate place in the sky and say la so, meaning, presumably, 'When the sun is like this.' This incident took place at the village of Maba, located by Van Gèle on his trip in 1886 and published in 1887 (for which see Cuypers 1960: 23). Because the phrase is attributed to chiefs and because it is located so close to that area where VS-speaking people are said to live in this century (see the map), one is justified in assuming that this was a VS phrase used by residents of Maba.

\subsubsection{Data for the year 1892 are rich.}

touque-touque aga 'the boat has come, is coming' (Masui 1894: $140)$.

All the morphemes in this sentence, the translation of which Masui did not 
provide, can be traced to VS. It is possible to interpret tuk-tuk as being a novel designation of mimetic origin for the little steamboats that were used on the Ubangi river, but it is also possible that it is derived from the VS ideophone tùkù-tùk $\dot{u}$ that refers to a side-to-side motion, as in $\dot{A} y i n g \grave{i}$ tìr ́̇ lò tùkù tùkù 'he turned back and forth' (Lekens 1958). In BG at that time $k u t u-k u t u$ was at least one of the words for steamboat, and this word had survived until very recently in PS for automobile. (The transposition of the consonants $\mathrm{k} / \mathrm{t}$ and $\mathrm{t} / \mathrm{k}$ does not, $\mathrm{I}$ think, pose a serious problem in this etymology.)

Complicating matters, however, is the fact that tuku-tuku is found in Wtterwulghe's word list (1899) for "la langue commerciale", that is, BG, and in Compagnies 1895, with the meanings 'soldier' and 'jigger' ('chique' in French.) It is easy to see how the meaning could have been transferred from 'soldier' to 'boat' (or vice versa) in the Bangala language. Since all these etymologies are reasonable, only an earlier attestation for $t u k u$ $t u k u$ in $\mathrm{BG}$ can determine which one is correct.

From Masui, who went to Banzyville in 1892, we also get n'zara mingi 'j'ai bien faim', but more accurately just 'hunger much' and $n$ 'susus 'fish' (1894: 135, 132). In the first case both words are Bantu and are probably derived from BG. In. PS one says $M b \bar{i}$ yèzkè nà nzàlà mingi ('I am with hunger much').

Masui's citation of nsusu may be a clue in the unravelling of the curious case of the fish. (I take the final ' $s$ ' in the text to be either an error or the plural from French, because it could not possibly be from any one of the local languages, none of which to my knowledge permits a syllable final /s/.) The PS word for 'fish' is, in fact, süsui, but it can be traced to no Ubangian language. VS has $k p \tilde{\imath}$, and GB, NGB, and $M Z$ all have si. Since we might find that there were dialectal differences between $s i$ and $s u$ and since monosyllabic words, as we have seen, seem to have been doubled by some speakers of the jargon, we could speculate that sùsù is derived from some MZ or GB dialect. But Masui's form, with an initial/ns/ could not be from a Ubangian language, where only /nz/ or some variant, is possible. We must recall, however, that Musy recorded mossou for 'fish' in 1889 (see table 1). It is possible to derive this from the BG form nsu cited in table 1, with the Bantu prefix mo replacing (a presumably lost) $n$. But this was not the most frequently cited form for $\mathrm{BG}$, which was samaki. It was cited only, as far as I know, by Morrison in Compagnies 1895. It is, however, attested for the vernacular of Monsembi in the form nsu, a language that was called at one time Bonsembi and at another Bangala, into which John H. Weeks translated the Gospel of St. Matthew (15:34; published in 1895 at Lukolela by the Baptist Missionary Society). Nsusu does occur in the early BG word lists, but with the meaning 'chicken', and it has this form and meaning in pidginized Kikongo, i.e. Fiote. What is 
curious about the 'chicken-fish' relationship with nsusu/susu is that it occurs with si as well. Although in our data and Calloc'h's for GB, it has the meaning 'fish', Thonner (1910) for the same language gives it the meaning 'chicken'! The parallel is too close to be accidental, but I have no explanation for it.

3.2.4. The single most important source of evidence for the ten-year period we are examining is that of Jacques de Crussol d'Uzès, who went up the Ubangi river in 1892, having left Marseille in April of that year. His diary (d'Uzès 1894), edited and published by his mother after his death in 1893, reveals him to have been an observant and inquisitive traveller. All the way up country he was noting words used by the Africans, and in the Bangui area he collected a "petit vocabulaire Banzyri" of 128 words and the numbers 1-9. In these we find ten words that have persisted in PS, and elsewhere in this work three more not identified as GB but also found in PS today, in addition to a few words already attested. Etymological analysis here also uncovers the multiple sources of the vocabulary of PS. Only the word for 'peanut' seems to be unique for the Gbanziri language. Three of the words are shared by some of the coterritorial languages, but it is not certain that this was the case in 1892 . I suspect that $P$. Calloc'h, who is my source for GB, NGB, and MZ words here, from time to time recorded PS instead of the vernacular, because his informants had got accustomed to using the contact-language words with foreigners.

Among these words that d'Uzès believed were GB are some Bangala ones. As we noted above, however, we are having to use the latter name as a cover term. Two of d'Uzès' words illustrate the problematic nature of this Bantu contact language (or set of Bantu jargons) while they also illustrate the remarkable diversity of the sources of the Ubangian jargons.

The word for 'tomorrow' is given both as cocoriko and kikeriki. The first form must be identified as the same as kokoriko provided by Wtterwulghe (1899) for 'matin de très bonne heure'; see also St. Norbert (1901). The only form known today in PS, with the meaning 'tomorrow', is kékèrékè (or kéérékè). In the absence of a cognate in a coterritorial language and because of the similarity between BG kokoriko and the mimetic lexicalizations of a rooster's crow in both French and some Nigerian languages (Paul Newman, personal communication), we can hypothesize that the onomatopoeic form is the source of the word. Many Nigerians (so-called Hausas) served as soldiers of the Etat Indépendant.

The other word is pepe, which must certainly come from some Bantu language on the upper Congo river. In his grammar of the "Congolese language", where he discusses various words for 'no', Cambier (1891: 336) says that pé-pé is found among the Ngombes. However, Thonner (1899) gives it as a Maginza word spoken at Liboko. 
Table 2. Etymological analysis of thirteen words used on the Upper Ubangi river in 1892 (d'Uzès 1894). Sources of data: (7) Wtterwulghe (1899); for abbreviations and other sources see table 1. The etymology of BG sanduku is Arabic.

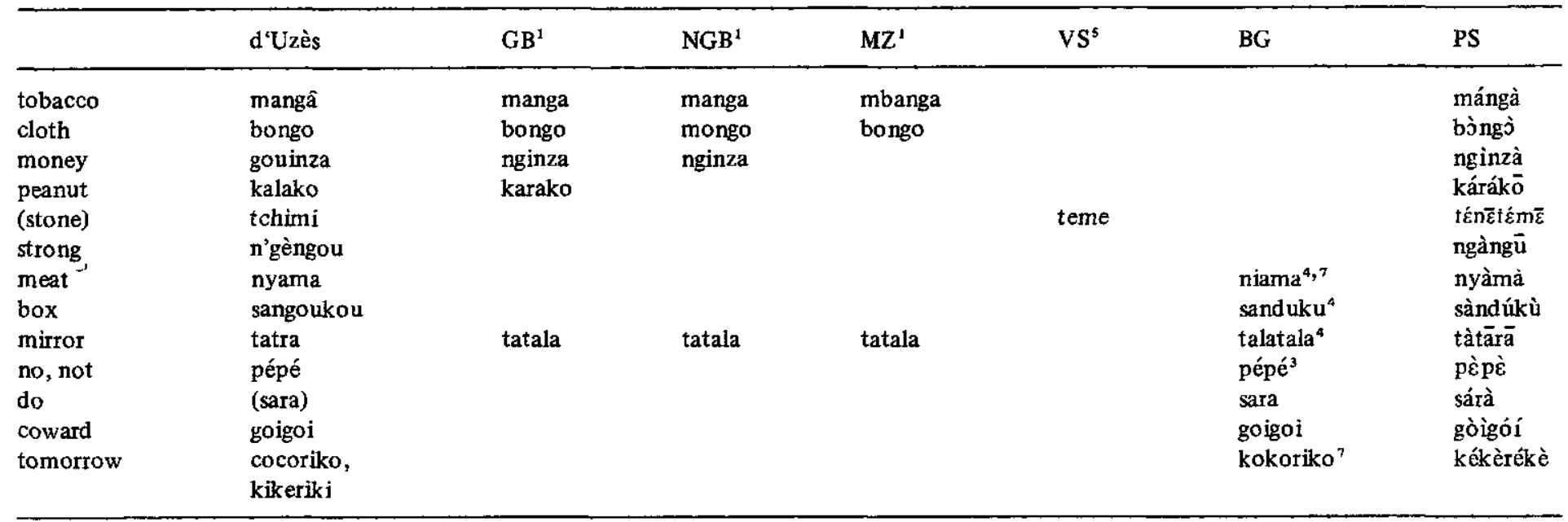


These "Ngombes" should be located not far from the Belgian post at Bangala (which came to have the name Nouvelle-Anvers), because $P$. Cambier was a missionary there. Moreover, we have Coquilhat's observation (1888: 207) that the Ngombe were scattered among the "districts" of Iboko and Mabali (actually the names of two towns). Although the Ngombe differ in scarification patterns and hair styles from the "ordinary" Bangala, Coquilhat points out that they are simply "gens de l'interieur" or bush people as opposed to river people. On the other hand, writing in July 1897, Bombeeck (n.d.: 27) says this about the Ngombe: "Les Bangalas [at Gundji or N'Gundji] comprennent difficilement le langage des Gombés de l'intérieur." As a matter of fact, the word Ngombe occurs in several different places in 19th century maps. Whatever the vernacular of P. Cambier's Ngombe may have been, some of its speakers would have been carriers of BG if they were in the employ of the Whites, which is very likely.

It is worth considering the possibility that these pepe speakers included (if they were not in fact the same as) Mongos, who were being used as soldiers by the Belgians. According to one early map (CI 1893) they would be located just south of the Lopori river, straddling $21^{\circ} \mathrm{E}$. in other words in the range of Ngombe distribution. But it was widely said in those days that the Mongos were found as slaves in many areas. Masui (1894: 81) mentions some at Equateurville on the Congo, and it was reported that almost all the imported slaves in the basin of the Ngiri river (which flows southward in the triangle between the Ubangi and Congo rivers, spilling into the former about $100 \mathrm{~km}$ above the confluence) were "Mongo" (BC 1895: 52-53). What is important about the possible relationship between the Ngombes and the Mongos is that it was Belgian policy at that time to impress into service slaves that had been liberated by the Whites. The whole crew of a small steamer as early as 1891 was composed of persons from the Lulonga river basin (Lemaire 1895: 15), where "Mongos" were certainly found. Such a local work force would explain both the incidence of pepe at a certain place and also the fact that these newcomers would themselves be learning the Congo Bantu jargon as well, possibly, as the Ubangi one. ${ }^{11}$

We would expect pepe to have come into the Ubangi as a free form - a word or interjection. This speculation is confirmed by Hulstaert (1950: 15), who points out that although pe (which he also writes $p \varepsilon$ ) is the negative prefix of the infinitive in the Ngombe language spoken along the Lulonga river, it is also used, either as pe or pepe, by the Ngombe on both sides of the Congo river to mean 'no'.

This negative is also cited for the year 1895 by P. Goblet (b. January 1869) in kama pépé 'plus camarade' (lit. 'friend no') said to a Sebanga chief ("mon chef Sébanga") for refusing to sell him slave children and for 
not giving him any gifts (Goblet 1932: 153); meaning, 'you are no longer my friend'. The Sabanga (which must certainly be a variant of this name) were said to be located just a two-day's walk (with direction unspecified) from Bangui (Ponel, AN/SOM-Aix, 4(3)Dl, Bangui, 15 April 1891); later, on the left bank of the Tomi (or Tomy) river (Gentil, AN/SOM-Aix, 2D11, 9 January 1896); and Huot (1902: 302) says that they are part of the Nzakara, which would put them a great distance east of Bangui. In Dybowski's map of 1891 (published in Dybowski 1893) the Tomi river is located just east of $17^{\circ} \mathrm{E}$ at about $5^{\circ} 50^{\prime} \mathrm{N}$, but in Lebègue (n.d.) it straddles $19^{\circ} \mathrm{E}$ and north of what is now Ft. Sibut. The discrepancy is easily explained by an error in the chronometric reading or one due to the use of 'dead reckoning' (Henry A. Gleason, personal communication). Kama is a GB word meaning 'brother'. At this time the BG word ndeko was being used on the river for 'friend', as in blood-brother transactions, and it is the proper word for 'friend' in PS today.

What is puzzling - but nonetheless symptomatic of the situation that we are faced with in writing this history - is that a Ngombe negative should have reached Gbanziri territory above the bend of the Ubangi river in (presumably) the Bangala language. The negative in the latter, by 1895 and even before that date, was the free form $t e$. Thus, in response to the question 'Is the bottle of wine full?' the answer is te, masanga atsazi na katikati "No, the wine is half"; in response to the question "Is there mud still on the path?" the answer is Atsazi kulu masusu te "There is none still' (Compagnies 1895).

The case of pepe supports my suggestion that there were several jargons on the Ubangi at the end of the 19th century. The carriers of pepe must have constituted one more-or-less homogeneous gang of workers at a given period of time on the left (the Belgian) bank of the Ubangi in a particular location; there must have been users of other forms of the negative.

Although the word for 'money' is attributed to the Gbanziri by d'Uzès (where it is spelled gouinza, but on page 220 as kinja) and by Calloc'h to both the Gbanziri and Ngbaka, the object in question is by others attributed to the Yakoma. Always of metal, it apparently took different shapes: hoe, shovel, plaque, or machete. Le Marinel (1891: 25) described the Yakoma region, i.e. the confluence of the Wele and the Mbomu, as the site of a veritable industrial center of considerable importance in the production of this currency. There were other forms of currency, e.g. red powder and beads, but iron was favored, at least over the beads. Both the Sango and the Gbanziri used it, the latter at Bangui (as early as 1892 if d'Uzès is our source, but certainly by 1897). The spelling with 'nj' suggests a dialectal variant of a word with $/ \mathrm{nz} /$ unles $/ \mathrm{nj} / \mathrm{was}$ the expatriate pronunciation or that of other Ubangians. Note, for example, that although Lekens' Ngbandi has $/ \mathrm{nz} /$, at least one variety of Mongwandi seemed to favor/nj/ (Thonner 
cordial forms. Swahili was present in the person of Zanzibari soldiers among Belgian personnel.

\section{6 kussala kobe kobe ('work food food') (Belgique Coloniale 1896:539)}

A Belgian officer who had been in the Congo for only five months, stopping at Zongo on his way to Yakoma with a contingent of soldiers (most of whom are Mongos), reports that this was said to him by a boy who had been assigned to him as servant at Zongo. Seeing that the White man was opening a can of food for his lunch, the boy comes and puts a question to him in these words. In the situation as described by the White the question might have had the meaning: 'Do you want me to cook you some food?' When the White does not understand, the boy makes some gesture of eating and shows him a live chicken he is holding in his hand. Still not understanding, the White makes an affirmative response, upon which the boy kills the chicken and prepares him a meal. (On internal evidence I speculate that this officer was Lt. Jean-Baptiste Th. Masui (see Masui 1894), who made a trip to Banzyville from Anvers in 1892 (FebruaryDecember). The date for kobe is therefore 1892 or 1896.)

Kusala is another BG word whose grammatical function here is as ambiguous as it was in BG as used by many Whites, and possibly non-indigenous Blacks, of that period. Consisting of the root sala and a prefix, it might be the infinitive or the present indicative, whose prefixes $k u$ and $k o$ were apparently confused by users of $\mathrm{BG}{ }^{12}$ For example, in the Petit vocabulaire (Compagnies 1895) Pauwels favors words with $k o$ and Morrison with ku (kobele/kubela 'sickness'; kobuka ,to paddle' / kubuka 'to break'), with 'to laugh' the selection is reversed: kuseka / kosheke. (The orthography is slightly altered in this paragraph.) Courboin, in a grammar (1908) that undoubtedly reflects BG before it was "improved", gives $k u$ for both the present indicative (e.g. ngay kulinga 'I love') and infinitive. De Boeck's 'literary' grammar (1911) has $k o$ in the simple present with a personal prefix: no-kokela 'I do'. Wtterwulghe (1899) uses both $a$ and $k u$ almost indiscriminately:

Gei [i.e. ngay] alingi asombi meme moko 'I want to buy a goat' ('I want buy goat one')

Gei kutambula lero te 'I will not march today' ('I walk today not')

Apesi na ngei koko moko 'Give me one chicken' ('Give to me chicken one')

Kuruba na mokota na nboka oyo 'Tell the chief of this village ...' ('Say to chief of village this')

D’Uzès (1894: 108) even gives $k a$ as an alternate of $k o$ : in the following: 
susu kasumba 'chickens to sell.' In PS kùsálà came to have a nominal function ('work'), whereas the verb, as has been mentioned, is simply sálà or sárà.

Kobe (PS $k \dot{b} b \dot{\varepsilon}$ ) 'staple dough or mush, prepared food, food in general' is not derived from VS and can be related only to Morrison's $k u b a$ 'food; plantations, food gardens' (Compagnies 1895). This is a reasonable etymon because of the phonetic similarity of the two back vowels, the frequent alternation between $/ a /$ and $/ \varepsilon /$ in the area, and the identification of Morrison's stressed syllable with the high tone of PS. On the other hand, since $\mathrm{BG} k o b a$ is similar to something in $\mathrm{BD}$, the latter language might be the source of kobe. Tisserant (1931) gives koba (kuba in the Ndri dialect) with the meaning 'limite de deux plantations, qui ont été débroussées ensemble'. It is, moreover, warrantable speculation to imagine that Morrison got koba from a southwestern Banda dialect. Yangere, for example, is found in at least three such locations on some maps. This speculation gets some support from Froment's location of the Ngoko river, mentioned above.

The repetition of kobe is anomalous. Perhaps the boy did repeat the word, meaning something like 'Food, food; do you want me to make food?' The White, on the other hand, may have interpreted the utterance in terms of what he had heard from other Whites about repetition as a linguistic phenomenon in this area. There is in VS, however, the word

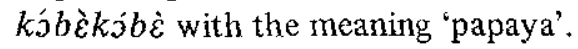

$$
\text { n'gou kouta ('water big') (Émily 1913: 360). }
$$

After the Fashoda incident, when the French forces under Marchand encountered those of the British on the Nile river, Emily proceeds to Djibouti. There, on 16 May 1899, many of his Blacks see the sea for the first time. Their exclamation is ngu kuta, whose translation Émily literally ("mot à mot") gives as 'l'eau grand'. Failure to give a free translation is evidence that he possibly did not understand the phrase at all. It is a somewhat grammatical sentence in both VS and PS, meaning 'The water [river, lake, or whatever] is big'.

Both of these words are from VS (although 'big' has been and is still found as $k \bar{o} t \bar{a})$. The absence of a copula marks the locution as being in the vernacular, which lacks a lexeme with this function. The pidgin came to have $y \grave{\varepsilon} k \dot{\varepsilon}$ or $\dot{\varepsilon} k \dot{\varepsilon}$, but even today it is not a categorical feature. We can therefore not be certain as to which language, VS or PS, this sentence must be attributed. Émily attributes its use to "nos tirailleurs et nos Yakomas", the former would have been for the most part Senegalese and the latter would have been for the most part porters and canoers.

We can argue that this was an exclamation in PS because of the absence 
of $n i$ following the attributive kuta. Lekens (1923: 25) says of Ngbandi that although the qualifying adjective ("hoedanigheidswoord") can follow a noun, it must always take the suffix ("achtervoegsel"). He translates locutions like yaka kotani as either 'a large garden' or 'the/a garden is large'. In contemporary PS the occurrence of $n i$ is not syntactically but semantically determined: ya $\bar{k} \vec{a} k \vec{o} t \vec{a} n i$, as I write it, is not even gram-

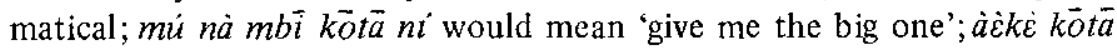
means 'it's big' and à $\bar{k} k \dot{\varepsilon} k \hat{o} t a \bar{~} n i$ would mean 'it's the big one' (for example, '. . that I want').

This locution cited by Emily might therefore be evidence of the loss of categorical $n i$ in PS. It might, on the other hand, be further evidence of the influence, this time syntactic, of Bantu speech. In these languages the usual position of the adjective is after the noun. Further evidence of this foreignism is found in the personal names cited above (Boy-Kéte' 'Junior Servant,' Boy-Kota 'Senior Servant'; Bangassou Kétté 'Bangassou Junior'). Support for this interpretation of the postposition of modifiers comes from Clerc's notes on 'commercial Sango' (1911: 303-304), where we find the following locutions, to which I add the contemporary PS ones where they are different (as the second entry), all in contemporary phonemic transcription:

\begin{tabular}{|c|c|}
\hline 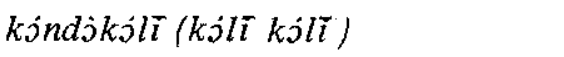 & 'cock' \\
\hline kj̉ndj wálī (wálī kj̉ndj̀) & 'hen' \\
\hline$k \dot{j} l \bar{i}$ mingi & 'many men' \\
\hline 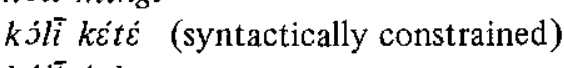 & 'few men' \\
\hline $\begin{array}{l}\text { kjli úsè } \\
k \dot{l i} \text { só }\end{array}$ & $\begin{array}{l}\text { "two men' } \\
\text { 'this man' }\end{array}$ \\
\hline
\end{tabular}

Support for the Bantu origin of this syntactic order comes also from the identical personal name once encountered in Lingala by Charles Gilman (personal communication): Boi Moke 'Junior Servant'. It must be noted, however, that in a few instances the syntactic borrowing has persisted, making a semantic difference in a way similar to that which obtains in French between preposed and postposed adjectives.

3.2.5. Having carefully examined the linguistic data for the Ubangi basin in the 19th century, we find that there are 36 lexemes known to this day in PS (see table 3).

Only 10 are traced to VS and 8 to two other coterritorial and related languages (NGB and GB). The rest are attributed to Bantu languages, 16 to Bangala. But in the latter case different varieties made their own contributions, the most remarkable instance being that of the negative. There is one case of metaphoric creation, that being the word for gun, and some 
Table 3. A summary, in chronological order of appearance, of words used in the Ubangi basin in contact situations and that have persisted in PS (here in simplified spelling), with possible etymologies, cxcluding those words for which there are cognates in several Ubangian languages. For abbreviations see table 1.

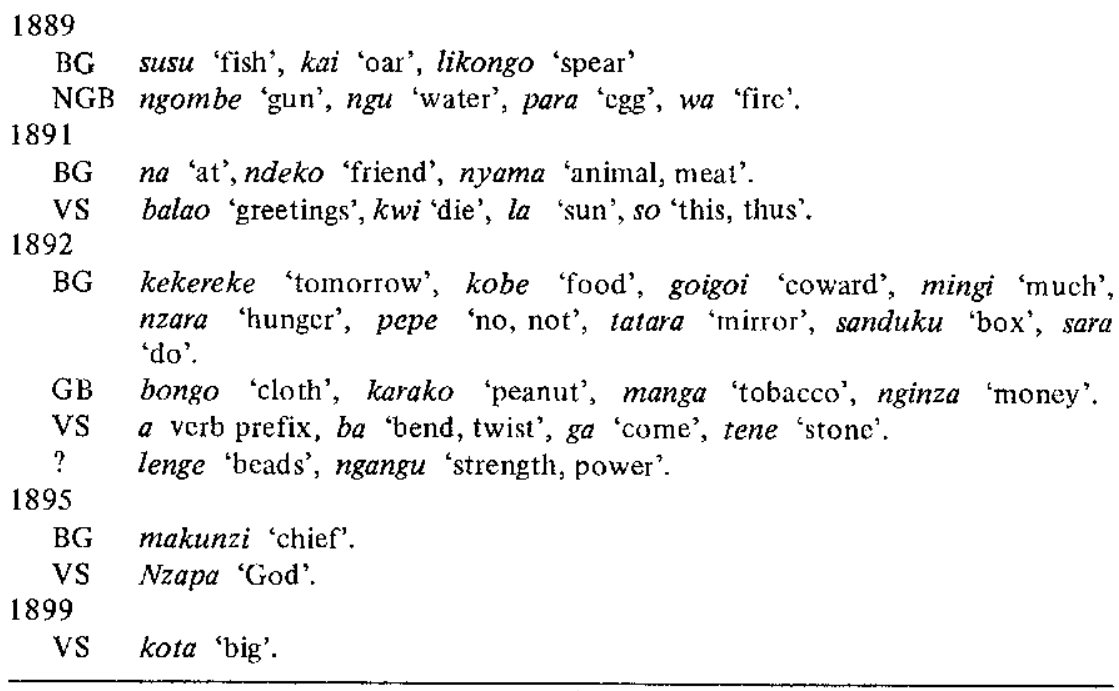

changes in meaning. The emergence of PS grammar is seen in the use of an interjection 'no' for the negative, modification in the use of $n i$, the postposition of certain adjectives, and the development of 'this' out of 'here'. All of this points to a complex origin for PS.

I may have unintentionally revived the notion of pidgins as "mixed languages" by what I have just described. This is a concept that has been out of favor ever since pidgins and creoles began to be studied by modern linguists. De Camp (1971: 15), for example, expresses linguistic orthodoxy, when he describes the expression as a "dangerous term" because:

\begin{abstract}
it not only begs the historical question but is also descriptively misleading, suggesting that a pidgin or creole is only a potpourri with no uniform coherent structure of its own. [Pidgins and creoles] are genuine languages in their own right, not just macaronic blends or interlingual corruptions of standard languages.
\end{abstract}

Although I prefer to sidestep the question as to the "mixed" nature of pidgins at this time, I must make clear that in this study I am primarily concerned with the "stuff" out of which PS emerged and not with what it came to be. Therefore I am indeed not begging the historical question. And in this connection it is important to note, as part of the historical record (as we saw above), that Whites believed (whether or not they ob- 
served accurately) that the Ubangi "river language" (as well as the Congo "river language") was a "mixed language".

The etymological analyses presented in this section, while critical to the writing of PS history, must be accepted, like all first attempts of this type, with reservations, Nonetheless, I am convinced that they suggest the nature of the kind of language that was used by Blacks and Whites on the Ubangi, out of which PS emerged. What these etymologies also reveal is the possibility of what has been called lexical fusion. In several cases, as we have scen, there are or might be multiple etymologies (or the reinforcement of one source by cognate forms from others). Moreover, we are taught by this exercise that the present-day composition of PS (which is about $80 \%$ VS) is not sufficient for fully understanding the formative period. For that we need to document the history of individual words.

\section{HISTORICAL INTERPRETATION}

In a period of about fifteen or twenty years at the end of the 19th century, PS came into existence on the Ubangi river in central equatorial Africa, emerging out of the contact between the indigenous peoples and the foreigners, Black and White, who came up the river from the south. It was not there, as far as I have bcen able to determine, on their arrival in any form whatsoever.

My claim is therefore different from that of Brucl, a colonial administrator who arrived on the Ubangi river in 1896, who was one of the earliest historians of French Equatorial Africa. In his discussion of commercial languages and sabirs he says that these "very simple 'passe-partout' languages" borrowed from other larguages that were easy to learn "vocables dont les règles grammaticales sont simples" (1935: 164). These languages, he says, spread with use on the part of the Blacks who were in the employ of the Whites. Sango was one of these sabirs, and when the Whites recruited the Gbanziri and the Buraka (the latter of whom, as far as I can tell, may belong to the same ethnic group) from just upriver of Bangui, these riverine peoples, who were in frequent contact with the Sango, already knew their language (1918: 170). But it is not clear whether this applies to the sabir or to the vernacular.

I make my counter-proposal confidently because Bruel provides no evidence to support his assertion about the prior existence of PS. Moreover, we can cite a convincing piece of negative evidence. Among the six languages for which Maistre (1895: 288-94) provided word-lists (in his spelling, Ballali, Batéké, Baschilangué (Kassai), Boubangui, Ndri, and Mandjia), there is nothing to suggest a sabir-type trade language for the Ubangi basin. Both Ndri and Mandjia are indigenous vernaculars, the first 
Banda and the second Gbaya. It should be recalled that Dybowski considered Ndri to be a contact language. There does not seem much likelihood that the incipient PS jargon was misnamed, because Maistre's $\mathrm{Ndri}$ is definitely BD although the list contains Bantu words, giving evidence again of the importance of Bantu speech at this time. (Maistre was in the area in 1892 and 1893.)

PS did not arise directly from the pidginization of VS. VS is not the Ubangian language with which the foreigners first came into contact. At the upper end of the Lower Ubangi (roughly, at its turn from northward to eastward) were found idioms of the Monzombo-Gbanziri dialect cluster, closely related Ngbaka ones, and Banda. Besides, during the period of 1885-1887 there had been only four visits by Whites to the area. The first real contact with VS territory did not take place until Van Gèle went up the Ubangi in December of 1887 , but this was brief and superficial. So it was not until his two year sojourn in the Ubangi basin (June 1889 to September 1891), most of it at the eastern end among the Zande-Nzakara, that there was the possibility of any intensive interaction with VS-speaking peoples. In the meantime, however, the French were establishing themselves at the western end, although in October 1890 Bangui is still cited as the "last French post" on the Ubangi (map by Paul Crampel and Edmond Ponel in Alis 1891), maintained with great difficulty by Ponel because of a shortage of men, ammunition, and other supplies (Kalck 1980: 108). In any case, after Van Gèle's departure Belgian presence became weaker, especially after the settlement of the French-Belgian boundary in this region in 1894.

In this account of the history of PS I have discounted the part that may have been played by contacts with VS in areas other than those on the Upper Ubangi. Although some 20th century maps show VS-speaking peoples on the Lower Ubangi (as do those of Van Overberghe and De Jonghe 1907, Lekens 1952, and Burssens 1958), others do not (for example, Thonner 1910). If one believes Lekens (1923), the Baati that Van Gèle encountered in this area in 1886 and the Mbati subgroups of Ngbandi around Abumombazi are related. Support for this view, which is not too convincing in Lekens - and against which I can argue also on onomastic grounds - might come, however, from the phrase cited by Fivé at Maba, which was discussed above. But it is not certain at all that la so was indeed used by the local inhabitants. Five could have cited something in translation, something that perhaps was said by one of his own personnel who was a native speaker of VS. For the time being, therefore, confronted with the magnitude and diversity of data at hand, we are not compelled to accept Bruel's assertion as correct. Only a new fund of data, especially Belgian in source, can lead to that view.

On the other hand, contacts were certainly made with VS groups in the 
Ubangi-Congo hinterland, where they are usually referred to as the Mongwandi. There were, for example, the expeditions by Hodister, Baert, Shakkerstron (or Schagerstrom), and Lothaire in 1890, 1891, 1892, and 1893 respectively (see maps in Boulger 1898 and du Fief 1900). What little we know about these contacts does not encourage speculation about the development of a VS jargon in these years. My impression is that the explorers were not so well received as they were on the Ubangi. Thonner (1899: 69), for example, mentions a number of Belgian posts, among which was Abumombazi, which had to be abandoned because of the hostility of the natives. Only at the southern limit of the territory that he attributes to the Mongwandi (or where one found round houses) were there trading posts ('factorcries') and military stations - ten altogether (Thonner 1899, map). Therefore, while I do not consider it impossible that the expeditionary forces picked up some VS, I do consider it unlikely that the Ubangi jargons were affected by this knowledge.

In about a dozen years, therefore, some of all the riverine peoples (Monzombo-Gbanziri, Ngbaka, Banda, Sango-Yakoma-Ngbandi-Dendi, Zande-Nzakara), in an area over $400 \mathrm{~km}$ in length, came in contact with the hundreds of foreign Africans in the service of the Whites. At first there was little focus in this contact. If the foreigners were acquiring the lexical means to effect some kind of communication, they were doing it in this language and that, whatever served their immediate needs from whatever was at hand.

The fact that there are 10 lexemes from VS and 8 from other Ubangian languages hardly suggests the contrary to what I am proposing. Some might nonetheless argue that the occurrence of these words so early in the record (say 1891 and 1892) points to the view that the dominant jargon early in the decade of 1890-1900 was indeed based on VS. Two considerations dissuade us from this position. The first is the absence of reference to a "Sango patois" that early. The second is that a detailed examination of the use of interpreters and guides by the French in this same period does not suggest this possibility (Samarin Ms. 2). In other words, there was no VS-based jargon in general use on the Ubangi river; but the Black cohorts, who were the usual sources of linguistic information, were finding it increasingly convenient to use VS words. The reason for this is to be found in the relationships between the French work and military forces and the indigenous populations.

Very soon, of course, VS began to be used as the main resource, and this has to be attributed to intensive Belgian efforts to establish their power in the Ubangi-Mbomu-Wele area. At the end of 1890 , for example, there were at Yakoma post already 150 indigenous men who had received military training (Cuypers 1960: 64). In 1891 Ponel complains about the arrival of the Belgians with 89 Yakoma to establish a post at Kouango, 
with 28 being left at Krisi-Mara (not yet located), pointing out, furthermore, that there were 200 men under instruction at Banzyville (Ponel, AN/SOM-Aix, 4(3)D1, Bangui, 30 March 1891). The following year, after Van Gèle had left the area, Yakoma men appear in the service of the French. De Poumeyrac, for example, in his expedition to punish and subjugate the Bubu (June 1892) had 12 Yakomas as well as 35 Nzakara to supplement his 11 Senegalese soldiers (Liotard, AN/SOM-Aix, 2D6, Abira, 24 May 1892). And as the decade went on more and more VS-speaking peoples were recruited by the French.

The Belgians and French were in hostile competition with each other during these critical years, which was reflected, naturally, in their dominion over the local populations. What unified them nonetheless was their dependence on Black personnel who had been recruited elsewhere and who arrived in the Ubangi basin speaking Bangala, already a somewhat stabilized pidgin, or interacting with each other in a Bantu-based jargon. It is this fact that accounts for the presence of $B G$ words in data we have examined.

Here again I must question the reliability of Bruel, who makes an explicit statement about the presence of $\mathrm{BG}$ at Bangui:

Dans notre Congo intérieur, jusqu'aux points terminus de la navigation: Bangui, Nola, etc., le Bangala a été propagé par les pagayeurs et les ćquipages de vapeur. Avant notre occupation, les Boubangui, proches parents des Bangala, faisaient du commerce jusqu'aux premiers rapides de la Sanga et de l'Oubangui. Par suite, ils avaient propagé leur langue et nous n'avons fait que hâter et faciliter la diffusion d'un sabir qui pré-existait déjà en grande partie et qui s'est augmenté de quelques mots zanzibarites ou arabes (1935: 165).

This is an important statement because of the assertion that the Gbanziri traded with the Bobangi at Bangui (1918: 307). What he is claiming, then, is that two simplified trade languages, PS and BG, came in contact at Bangui before the Whites arrived. While the possibility of Bobangi traders in the Bangui area is not improbable (although Whites may have been misled by the homonymy of the Ngbaka clan name and that of the totally unrelated Bobangi from the Congo river), it is not at all certain that BG existed as a pidginized contact medium before Stanley's men put up their first base at Bangala in 1884 .

There is, of course, a logical reason why it is not credible to assert the presence of $\mathrm{BG}$ at the bend of the Ubangi river before Whites arrived. If that had been the case, then the arrival of hundreds (possibly hundreds upon hundreds) of BG-speaking Blacks with the Whites would have established that language at the expense of all other jargons.

But the speakers of BG are as important to the history of PS as the 
language itself, perhaps more important, in view of the fact that all the foreigners were not equally competent in this pidgin. We must assume that only some of them had some knowledge of some form of BG. There was a great deal of variation in the form this language had (if it could be called that at all) and there certainly must have been in the speakers' ability to use it. It was therefore sociolinguistic competence more than linguistic competence in "Bangala" that characterized these thousands of Black cohorts who penetrated the Ubangi basin: thcy had acquired the skill to "make do" in linguistic interaction. It was easier downriver, of course, because all the languages were Bantu. Here on the Ubangi all of a sudden they were confronted with new phenomena. But they had had experience in getting along.

I have been using "Bangala" as the Bantu contact language that had an impact on the Ubangian jargons. But I have not tried to conceal the fact that although it may have been stabilized by the 1890 s, it was far from uniform. Moreover, there is reason to believe that $\mathrm{BG}$ was not the only influence on the Ubangi. The various work forces must have brought with them different repertoires, depending on their place of origin (ethnicity) and experience. And there must certainly have been a difference between the Belgian and French expatriate work forces. An analysis of the different work forces (both their ethnic and geographical origins and also their numbers) will help to clear up this matter.

In any case, PS must be linked both linguistically and sociolinguistically to a remarkable chain of contact languages that emerged in the equatorial belt of Africa in the 19th century: first to Bangala, which in turn is linked to pidginized Kikongo (which must be linked in some way to Pidgin Portuguese and Pidgin English). In the emergence of BG, Stanley's Swahili-speaking Zanzibaris also had a great part. The implications of these relationships both in the linguistic and social histories of this part of Africa will have to be worked out in the future. ${ }^{13}$

"Broken" VS was therefore only one of many "broken" forms of speech on the Ubangi, and the emerging contact jargon could just as easily have been Gbanziri as Sango. There is certainly no linguistic reason for the "winning out" of Sango. It was primarily a matter of people, time, and circumstances - an "accident".

I hypothesize, then, that although VS came to provide the base for PS, it was not its direct source. But things happened very quickly indeed, and the time between the existence of a variety of ad hoc jargons or broken idioms and the emergence of VS as a target of language learning or the focus of language use was remarkably brief.

It must now be made explicit that VS in this study has been and cannot be anything but a construct that facilitates discussion about the history of PS. There is no evidence that a single dialect, whether its name was Sango 
or not, served as the basis of the jargon that came to be PS. Indeed, I should say that this was very unlikely. It is more reasonable to believe that several dialects contributed to the pool of material; six is not an unreasonable number, and one cannot argue even against a dozen. More important than the number of dialects, however, is the parallel event that took place in this dialect cluster: at each site where "VS"-speakers were interacting with foreigners, pidginization was going on. And then circumstances swept all of the consequences together, and these were unified and eventually systematized either by the foreigners or by both the foreigners and the speakers of VS idioms.

\section{CONCLUSION}

This paper provides linguistic and historical evidence for the process that led to the emergence of Pidgin Sango. It does not attempt to demonstrate exactly when it became a pidgin language. What we have seen is that words from different sources, but mostly from VS and BG, were being used together. Words were changing in meaning, sometimes drastically, and grammatical innovations were appearing.

It is surprising how much we have been able to learn with such limited linguistic data. We have used them with the greatest of caution, bringing every means of criticism and evaluation we have at our disposal, fully aware, moreover, that we cannot be sure of the accuracy and authenticity of the data. We know practically nothing about how the Whites made their observations. I am inclined to believe that they relied heavily on what their BG-speaking Black companions told them and that little was obtained by personal interaction with Ubangians themselves. If this is so, it is further evidence of the role these cohorts played in the "creation" and use of PS.

What makes the interpretation of the linguistic data possible is not only other linguistic facts, but also facts that are historical in the broadest sense. It is possible to write the true history of Pidgin Sango only in connection with the writing of the history of Belgian and French colonization in the Ubangi basin. While the present paper demonstrates that this is true, the full account must be presented elsewhere when attention is given to nonlinguistic matters.

APPENDIX: A chronology of White occupation of the lower and middle Ubangi basin in the 19 th century

1877, Aug.

Henry M. Stanley arrives at Boma on his cross-Africa journey. 
1879

1883, May

1884, $\Lambda$ pr.

1884, May

1884 , Oct.

1885, Jan/Feb .

1885, May

1886, Oct.

1887 , Nov.

1887, Dec.

1888, Jan.

1888, Feb.

1888 , Sep. ?

1889, May

1889, Jan./Apr.

1889, June

1889 , July/Aug.

1889, Aug.

1889 , Oct./Nov.

1889, Dec.

1890 , May

1890, Aug.

1891, Mar.

1891 , June-July

1891, Summer

1891, Aug.

1891, Sep.

1891, Oct.

1891, Dec.

1892, Apr.
Stanley starts up the Congo eastward for the first time. Stanley starts on his first trip to the Equator area.

Edmond Hanssens and Alphonse Van Gèle discover the Ubangi river, going as far as $0^{\circ}-1^{\prime} \mathrm{N}$.

Bangala station is founded for the Belgians.

George Grenfell, English Baptist missionary, reaches a point $130 \mathrm{~km}$ up the Ubangi at $0^{\circ}-25^{\prime} \mathrm{N}$.

Grenfell arrives at the rapids of Zongo (others say Bonga, $30 \mathrm{~km}$ downriver of Zongo).

Albert Dolisie (French) arrives at between 2-3 ${ }^{\circ}$. N.; French post at Kundja has been founded already for several months (or has just been founded).

Van Gèle arrives at and names the site of Zongo, but does not go further (others say October 1885).

Dolisie arrives at what will become Bangui; Van Gèle claims the territory around Zongo for the Congo Free State.

Van Gèle camps at Banzy (later to become Banzyville) and discovers the Mbomu river.

Dunod on the French steamboat "Alima" goes as far as rapids at $4^{\circ} \mathrm{N}, 17^{\circ} \mathrm{E}$.; Van Gèle has battle with Yakoma. Van Gèle arrives at Leopoldville on way to Europe.

French post is founded at Modzaka.

Van Gèle leaves Leopoldville for the Ubangi; French post is founded at Bangui (May-June).

Roman Catholic mission of St. Louis is founded at Liranga.

French post is founded at Bangui and Belgian at Zongo. Belgian post is founded at Mokwange.

Construction begins at Bangui.

Mgr. Augouard and PP Allaire and Moreau start from Brazzaville to go up the Ubangi on missionary exploration. Van Gèle explores the lower Kotto river.

Belgian posts are founded at Yakoma and Bangassou.

French expedition under Paul Crampel leaves Brazzaville for Ubangi.

Belgian post is found cd at Kouango.

French expeditions under Gaston Gaillard and Léon Masredon de Poumeyrac go up the Ubangi from Bangui.

Commercial "factories" are placed by Belgians at Zongo, Banzyville, Yakoma, and Bangassou.

Gaillard founds French post at Abiras on the Wele river; French expedition under Jean Dybowski arrives at Bangui. Van Gèle leaves Yakoma to return to Europe, turning command over to George Le Marinel.

French post is consolidated at Abiras by de Poumayrac and others established by Gaillard at Yakoma and Mobaye. French expedition under Victor Liotard leaves Brazzaville for the Ubangi.

French expedition under Casimir Maistre leaves Brazzaville for the Ubangi and that of Jacques de Crussol d'Uzès leaves Marseille for Ubangi. 


\author{
1892, Spring \\ 1893, Early \\ 1894, March \\ 1894 , Oct. \\ 1894, Nov.
}

$1896-1897$
Dutch "factory" is placed at Bangassou.

Mgr. Augouard visits Bangui to select site for mission.

French expedition under Émile Julien arrives at Abiras. Mission of St. Paul des Rapides is founded near Bangui. Mission of Ste. Famille des Ouaddas is founded among the Gbanziri.

Great expedition to the Nile under Jean-Baptiste Marchand.

\section{NOTES}

1. Sango is the national, although not official, language of the Central African Republic and is spoken across the borders of some of the adjoining countries. For a bibliography see Reinecke et al. (1975) and subsequent works by Bouquiaux et al. (1978), Diki-Kidiri (1976, 1977), Samarin (1980), and Samarin and Diki-Kidiri (1982).

2. The name Ngbandi is misapplied by Hancock (1971:518) to Pidginized Swahili spoken in Zaire. What he undoubtedly meant is Kingwana, but known by other names as well, for example, Shaba Swahili.

3. The history expressed in this paper is my own, based on extensive reading of 19 th century sources, published and unpublished, as well as various histories of the period we are concerned with. I list here only those sources used in establishing the appendix: AN/SOM-Aix 4(3)D1, 11 June 1981; Alis (1891); Cuypers (1960); de Dampierre (1967); Dybowski (1893); Fivé (1906); Fourneau (1932); Froment (1889); Galinand (n.d.); Kalck (1970, vol. 2); Lejeune (1930); Petit (1894); Veistroffer (1933).

4. Jean-René Calloc'h (1875-1928), like several of his fellow missionaries, was from Brittany in France. He was ordained a priest in 1899 , left for Africa for the first time in April 1901, and was consecrated as Monscigneur in 1914. He first learned the Teke language in Brazzaville, in which he translated the catechism less than a year after his arrival. In 1904 he published a manual of conversation and a reading primer in Teke. When he went to Notre-Dame des Bouroussés, $45 \mathrm{~km}$ from Bangui, he was already "in possesion of several idioms of the country" around Brazzaville. He later became Superior of the Mission St. Paul at Bangui and then Préfet apostolique de l'OubanguiChari (Calloc'h 1929).

5. The memorandum comes from the "L'inspecteur d'État faisant fonction du gouverneur général", dated at Boma, 1 July 1895, Appendice $\mathrm{N}^{\circ} 4$, Intérieur $\mathrm{N}^{\circ} 41$, and is (or was) to be found in the "Recueil Officiel des ordonnances, arrêtés, circulaires, instructions et ordres de services, juillet 1895, pp. 15-16)". Leaving out the paragraph that encourages the use of the French language, we cite the document:

Circulaire rappelant la nécessité de former des divers dialects indigènes.

À différentes reprises, j'ai eu l'occasion de rappeler la nécessité de réunir, dans tous nos districts, les éléments nécessaires à la rédaction de vocabulaires des divers dialects indigènes employés dans l'État.

J'attire, à nouveau, l'attention des commissaires de district sur ce point d'une très réelle importance.

Pour que nos relations avec les indigènes portent des fruits, il est indispensable que nos agents aient à leur disposition les moyens de se familiariser avec les idiomes employés par les populations chez lesquelles ils séjournent. 
6. By using the word volapük Goblet scems to be implying both that the jargon is an interlingual means of communication, and, like the international language by this name, an artificial one. What is curious is the animosity expressed in the statement. It may have been due to a French attitude to the German origin of volapük, which was published in 1880 by Johann Martin Schleycr (1831-1912), soon after the disastrous wat of 1871 , but it may have been due also to what was of Belgian origin in this jargon.

7. The recruitment of children as well as redemption of slave (or 'slave') children by Whites, especially missionaries, played an important role in Black-White relations in this period. The case under discussion is cited in AA, 1894, 9(35): 90; Rćmy, CSE III.170-A.5; Chapiseau (1900: 38-39) cites another case for 1891.

8. My data on these three languages were collected in 1953 during a single weekend at Mongoumba. My transcription of tone must therefore be taken with reservation. 9. Another etymology for lolo would link this word with the VS $o 0^{-}$'this', for in that language there is the phrase lá ó $l^{-}$'today' ('sun' + 'this'). There is therefore reason to speculate that there might have been a biend of $\mathrm{BD}$ and VS in the contact language.

10. I am deeply indebted to P. Ghislain de Banville (C.S.E.) for a photocopy of this apparently hitherto uncited but extremely valuable work on Bangala, taken from an original in the possession of Mlle Cureau, daughter of Lieutenant-Gouverneur Adolphe Cureau. P. Ghislain speculates that it was used by Dr. Cureau at the time of the Franco-German expedition in 1901-1903 to determine the boundary of the CongoCameroun and that it may be dated as early as 1895 or 1897 . For this reason I give the date as 1895 . (Close similarities between this work and Wtterwulghe 1899 suggest the latter borrowed from the former.) The work consists of French-Bangala and Bangala-French entries (without Bangala being identified as such) in columns comparing the submissions of two of the Compagnies' agents Leon Morrison and Ferdinand Pauwels, followed by useful phrases. It was published by the 'pierre humide' process with handwritten imprint. The N'Goko river in the name of the company appears in only a few maps. It may be the same as the Ngouco whose location is taken as problematic in Wauters' map of 1887 . Boulger (1908) shows it as the western tributary of the Sanga where it meets the Masa at the southeastern boundary of the Cameroun. But Froment's map of 1889 shows it at $2^{\circ} \mathrm{N}$ and $15^{\circ} \mathrm{E}$, not far at all from the Ubangi, although in dotted lines.

11. After this paper was completed and while examining my data on the French personnel, I discovered that in June 1891 there were some liberated 'Loulongo' slaves serving as "auxiliary workers", seven of whom are named (Ponel, Bangui, 1 June 1891, AN/SOM-Aix 4(3)D1). These seem to be at Bangui. It is not clear where they had been liberated. If this was in the Bangui area, we must assume that there might have been speakers of a pepe language there before the Whites arrived, but the facts are not yet clear enough to compell us to assert the pre-existence of a stabilized pidgin.

12. Charles Gilman suggests (in a personal communication) that the difference between $k u / k o$ is due to the phonological differences between upriver and downriver vernaculars. In the latter there is a five-vowel system. "This is", he says, "an important shibboleth separating Equator speakers from Kinshasa speakers".

13. In other areas of the world greater attention must be paid to similar linkages and overlayings of contact languages. They are found in the Pacific area, according to Peter Mühlhäusler (personal communication), and in the Mississippi river basin, Drechsel (1981: 10n) speculates, a Creek-based contact language may have been linked to Mobilian Jargon via a community of former slaves to produce what is now known as Afro-Seminole Creole. 
$\uparrow$ After going to press I learned from the accounts of Savorgnan de Brazza's explorations in the Lower Congo area in the late 1870 s that the French were indeed referred to as Fara.

\section{REFERENCES}

Archives and Periodicals

AA. Annales Apostoliques de la Congrégation du Saint-Esprit et du SaintCoeur de Marie.

$\mathrm{AAB}$. Archives Africaines, Ministère des Affaires Etrangères et du Commerce Exterieur, Bruxcllcs. 2ème Section, Première Partie, Varia: Voyages, missions et explorations au Congo 1885-1905, A.i (1143), Dossier 5. (See Gillaert).

ASOM. Académie des Sciences d'Outre-Mer, Paris. (See Brucl).

AN/SOM-Aix. Archives Nationales, Section Outre-Mer, Aix-en-Provence, France.

BC. La Belgique Coloniale.

CI. Le Congo llustré.

CSE. Congrégation du Saint-Esprit et du Saint-Coeur de Marie, Paris and Chevilly-Larue, Ftance (the Holy Spirit Mission); Journal de la communauté: St. Paul des Rapides, Bangui. 1894-1898.

MH. Missionary Herald (Baptist Missionary Society, London, Fingland).

MC-P. Ministère des Colonics, Paris. (See Julien).

Authored Works, Published and Unpublished

Alis, Harry [pseudonym of Jules-Hippolyte Percher]. 1891. Á la conquête du Tchad. Paris: Hachette.

Baratier, (Général). [1897]. Vers le Nil: souvenirs de la Mission Marchand de Brazzaville à Fort Desai. Paris: Arthème Fayard \& Cie.

Bloomfield, Leonard. 1933. Language. New York: Henry Holt.

Bombeeck, Harry. n.d. Notes et souvenirs du premier terme passé à l'État indépendant du Congo (1896-1899) pour le compte de la 'Société Anonyme belge pour le Commerce du Haut Congo' (S.A.B.). No place. Mimeographed. 52 pp.

Boulger, Demetrius Charles de Kavanagh. 1898. The Congo State: or the growth of civilisation in Central Africa. London: W. Thacker and Co.

Bouquiaux, Luc, et al. 1978. Dictionnaire Sango-Français et lexique Français-Sango. Paris: SELAF.

Brachiel, G.H. 1909, Vocabulaire Sangho (Haut Oubangui). Paris: J. Boyard.

Bruel, Georges, Lettres de G[eorges] Bruel à sa proche famille durant son premier séjour. ASOM. Dossiers B1 (1895-1896), B2 (1897-1898).

- 1918. L'Afrique Équatoriale Francaise: le pays, les habitants, la colonisation, les pouvoirs publics. Paris: Larose; Rochefort-sur-Mer: A. Thoyon-Thèze.

- 1935. La France Équatoriale Africaine: le pays, les habitants, la colonisation, les pouvoirs publics. Paris: Larose.

Brunache, Paul. 1894. Le centre de l'Afrique. Autour du Tchad. Paris: Ancienne Librairie Germer Baillière \& Cie.

Burssens, H. 1958. Les peuplades de l'Entre-Congo-Ubangi (Ngbandi, Ngbaka, Mbandja, Ngombe et Gens d'Eau). (Annales, Sciences de l'Homme. Monographies Ethnographiques, vol. 4.) Tervuren: Musée Royal du Congo Belge.

Calloc'h, (P.) Jean-René. 1911. Vocabulaire Français-Gmbwaga-Gbanziri-Monjombo précédé d'éléments de grammaire. Paris: Paul Geuthner. 
1929. [Nécrologie]. Bull. de la congrégation de Saint-Esprit 21(461):56-66.

Cambier, (P.) É. 1891. Essais sur la langue congolaise. Brussels: Imprimerie Polleunis \& Ceuterick.

Challaye, Fúlicien. 1906. Le Congo Francais. Paris: Cahiers de la Quinzaine.

Chapiseau, Félix. 1900. Au pays de l'esclavage: moeurs et coutumes de l'Afrique centrale, d'après des notes recueillies par Ferdinand de Béhagle. Paris: J. Maisonneuve.

Chaudenson, Robert. 1977. Toward the reconstruction of the social matrix of creole language. In Pidgin and Creole Linguistics, ed. A. Valdman, pp. 259-76. Bloomington: Indiana University Press.

Clerc, M. 1911. Grammaire sango. Bull. et Mémoires de la Socièté d'Anthropologie de Paris 2(3,4):303-19 (6th serics).

Compagnies des Produits de la Sangha et de la N'Goko. n.d. Petit vocabulaire commercial Français-Congolais et Congolais-Français à l'usage des nouveaux arrivants dans les régions occupées par la moyenne Sangha et la N'Goko . . . . . .

Congo Belge. Archives: Section Documentation. 1958. Document pour servir à la connaissance des populations du Congo Belge: aperçu historique (1806-1933) de l'étude des populations autochtones. Leopoldville.

Coquilhat, Camille. 1888. Sur le Haut-Congo. Paris: J. Lebc̀gue \& Cie.

Cordell, Dennis D. 1977. Dar al-Kuti: A History of the Slave Trade and State Formation on the Islamic Frontier in Northern Equatorial Africa /Central African Republic and Chad) in the Nineteenth and Early Twenticth Centuries. Ph.D. dissertation, University of Wisconsin.

-. 1979. Blood partnership in theory and practice: the expansion of Muslim power in Dar al-Kuti. J. Afr. Hist. 3:379-94.

Cotel, (P.) Pierre. 1907. Dictionnaire Franģais-Banda et Banda-Français avec un essai de grammaire Banda et exercices de conversation. Brazzaville: Mission Catholique.

Courboin, A. 1908. 'Bangala': langue commerciale du Haut-Congo. Éléments et manuel de conversation. Lexique. Paris: A. Challamel; Brussels: Office de Publicité, Lebègue; Antwerp: 0 . Forst.

Cuypers, J.P. 1960. Alphonse Vangèle (1848-1939), d'après des documents inédits. (Mémoires in $-8^{\circ}$. Classe des Sciences Morales et Politiques. Nouvelle Série. Histoire, vol. 24, no. 2.) Brussels: Académie Royale des Sciences d'Outre-Mer.

De Boeck, (P.) Égide. 1911. Grammaire et vocabulaire du Lingala. 2nd. ed. NouvelleAnvers, Congo Belge: Imprimerie des Socurs Franciscaines, Mission du SacréCoeur.

-_. 1940. La langue ngbandi. Aequatoria 3(4):110-111.

de Dampierre, Éric. 1967. Un ancien royaume Bandia du Haut-Oubangui. Paris: Plon.

DeCamp, David. 1971. Introduction: the study of pidgin and creole languages. In Pidginization and Creolization of Languages, ed. Dell Hymes, pp. 13-39. Cambridge University Press.

Diki-Kidiri, Marcel. 1976. Développement du sango pour l'expression du mondc moderne: obstacles et possibilités. In Les relations entre le francais et les langues négro-africaines, pp. 717-28. (Actes du Colloque de Dakar, 19 au 25 mars). Paris: CILF [Centre international de la Langue Francaise].

_- 1977. Le sango s'écrit aussi: esquisse linguistique du sango, langue nationale de l'Empire Centraficain. Paris: SELAF.

Drechsel, Emanuel J. 1981. A preliminary sociolinguistic comparison of four indigenous pidgin languages of North America (with notes towards a sociolinguistic typology in American Indian linguistics). Anthropological Linguistics 23:93-112.

du Fief, J. 1885. La question du Congo. Bull. de la Société royale belge de Géographie 9:221-99. 
d'Uzès, Duchesse. 1984. Le voyage de mon fïls (Jacques Marie de Crussol, Duc d'Uzès) au Congo. Paris: Plon, Nourrit \& Cie.

Dybowski, Jean. 1893. La route de Tchad du Loango au Chari. Paris: Firmin-Didot.

Dyé, A.H. 1899. Les pagayeurs du Haut-Oubangui. Bull. de Comité de l'Afrique Francais 9(12):444-47.

Émily, J. 1913. Mission Marchand: journal de route du Dr. J. Émily. Paris: Hachette \& Cie.

Fivé, (Génćral). 1906. Moeurs et Coutumes. (Causerics du Mercredi. Cercle Africain. 28 Novembre 1906.) Brussels: 'Travaux Publics.

Fourneau, Alfred, 1932. Au vieux Congo. Notes de route 1884-1891 (avec annotations de G(eorges/ Bruel). Paris: Comité de l'Afrique Française.

Froment, Ed [mond]. 1889. Un voyage dans l'Oubangui de Lirranga à Modzaka. Bull. de la Société de Géographie de Lille 11:180-216.

Galinand, (P.) Joseph. n.d. Le R.P. Allaire, missionaire au Congo d'après ses écrits et sa correspondance Paris: H. Oudin.

Gillaert, (P.) L. n.đ. Les langues bantoues sont-elles d'origine monosyllabiques. AAB. Typescript.

Girard, Henry, 1901. Yakomas et Bougous: anthropophages du Haut-Oubanghi. L'Anthropologie 12:51-91.

Giraud, Gaston. 1908. Vocabulaire des dialectes Sango, Bakongo et A-Zandé. Paris: Ministère des Colonies; Augustin Challamel. (Reprinting of publication in Revue Coloniale, New Series 58, January 1908).

Goblet, (Abbé) F. n.d. Joumal et correspondance du R.P. Raoul Goblet, DubanguiChari, 1894-1897. Journal de voyage et correspondance addressé à son Frère, l'A bbé Frédéric Goblet. Paris: Orphelins- Apprentis . . . . . . . .

Goblet, (P.) Raoul. n.d. Journal du R.P. Raoul Goblet, missionnaire apostolique de l'Oubanghy à la Mission de la Sainte Famille des Banziris. CSE Archives V, Boite 181, Dossier B.

Hancock, Ian F. 1971. A survey of the pidgins and creoles of the world: a map and list. In Pidginization and Creolization of Languages, ed. Dell Hymes, pp. 509-23. Cambridge University Press.

Heymans, (Cpt.) 1896. La zone Mokoangai. La Belgique Coloniale 2(29):342-45; $2(30): 354-56$.

Huot, (?). 1902. Les peuplades de l'Oubangui et du Baht-el-Ghazal. Revue Scientifique 17:301-306. (Extract from Annales d'Hygiène et de Médecine Coloniales, 4 th series, 39 th year, No. 10.)

Hulstaert, G[eorges]. 1950. La négation dans les langues congolaises. Mémoires. Collection in- $8^{\circ}$. Section des Sciences Morales et Politiques, vol. 19, no. 4.) Brussels: Institut Royal Colonial Belge.

Johnston, (Sir) Harry. 1908: George Grenfell and the Congo: a history and description of the Congo Independent State and adjoining districts of Congoland ..., 2 vols. London: Paternoster Row (New York: Kraus Reprint [1969]).

Julien, Émile Pierre François. 1899. Itinéraire à travers le bassin de la rivière 'Banghi' et les pays Bougbou, Yapa, Adama par M. le Capitaine Julien. MC-P. Mission 25, Dossicr Julien 1899.

Julien, Émile Pierre François. 1902. Map: Itinéraire de la haute Banghi. La Géographie $5: 216$.

Kalck, Pierre. 1970. Histoire Centrafricaine des origines à nos jours. Thèse présentée devant la Faculté des Lettres et Sciences Humaines de Paris. 2 vols.

- 1974 . Histoire de la République Centrafriçaine des origines préhistoriques à nos jours. Paris: Berger-Levrault. 
1980. Historical dictionary of the Central African Republic. Translated by Thomas O'Toole. (African Historical Dictionaries, 27), Metuchen, N.J.: Scarecrow Press.

Lebègue, J. \& Cie., Paris n.đ. Carte de l'État Indépendant du Congo d'après les renseignements fournis par les explorateurs et par la Mission Scientifique Belge $1: 4,000.000$.

Lejeune, Léo. 1930. Le vieux Congo. Souvenirs recueillis par Léo Lejeune. Brussels: L'Expansion Belge.

Lekens, (P.) Benjamin. 1923. Spraakkunst der Ngbanditaal. Bruge: K. Beyaert / C. Houdmont-Cortvriendt.

-..- 1952. Dictionnaire Ngbandi (Ubangi, Congo Belge). Français-Ngbandi, NgbandiFrançais. (Annales. Série in- $8^{\circ}$. Sciences de l'Homme. Linguistique, Vol. 1.) Tervuren: Musée Royal du Congo Belge; Antwerp: Sikkcl.

- 1955,1958 . Ngbandi idioticon, 1. Nederlands-Frans en Ngbandi: Ngbandi idioticon, 2. Ngbandi en Frans-Nederlands. (Annales, Série in- $8^{\circ}$. Sciences de l'Homme. Linguistique, vol. 3.) Tervuren: Musée Royal du Congo Belge.

Lemaire, Charles François. 1894a. La numération dans la région des cataractes. $L e$ Congo lllustré 3:146.

_- 1894b. La numération parlée. Le Congo Mlustré 3:162, 164.

1895a. Au Congo: comment les noirs travaillent. Brussels: Bulens.

-_. 1895b. La région de l'Equateur. (Trois conférences économiques. Société d'Etudes Coloniales, 1894). Brussels: A. Lesigne. (Also entitled Districts des Cataractes et de l'Equateur).

- 1897 . Vocabulaire pratique: Francais, Anglais, Zanzibarite (Swahili), Fiote, Kibangi-Irébou, Mongo, Bangala. 2nd ed. Brussels: Imprimerie Scientifique Ch. Bulens.

Le Marinel, Georges Édouard. 1891. Exploration du Kotto. Mouvement Géographique, 144.

Maistre, Casimir Léon. 1893. [Report of journey in 1892-1893]. Société de Géographie[de Paris]: Comptes rendus des séances, nos. 12-13. Séances de 9 et 16 Juin 1893 , pp. $270-287$.

-._.. 1895. A travers l'Afrique centrale du Congo au Niger 1892-1893. Paris: Hachette \& Cie.

Mamet, M. 1960. Le langage des Bolia (Lac Léopold II) telle qu'elle est parlée au Lac Ntumba et dans la région avoisinante (Afrique centrale). (Annales. Sciences de l'Homme, vol. 33). Tervuren: Musée Royal du Congo Belge.

Masui, Jean-Baptistc Théodore. 1894, D'Anvers à Banzyville: lettres illustrées du Lieutenant Masui. Brussels: Bulens.

Musy, Maurice. 1890-1891. Correspondance de M. Maurice Musy, chef de poste à Bangui (Congo français), massacré par les indigènes. Revue de Géographie 27: 375-81, 455-57 (1890); 28:64-68, 130-33, 211-14, 291-94; 29:62-66 (1891).

Nida, Eugene A., and Harold W. Fehderau. 1970. Indigenous pidgins and koinés. Int. J. Am. Ling. 36:146-55.

Petit, Edouard. 1894, 1895. Organisation des colonies françaises et des pays de protectorat, 2 vols. Paris, Nancy: Berger-Levrault \& Cie.

Pourbaix, V., and J. Plas. 1899. Le régime économique et les sociétés commerciales du Congo français. Brussels: A. Lesigne.

Reclus, tlisée. 1888. Nouvelle Géographie Universelle: la Terre et les Hommes. Vol. 12, 13 (Afrique). Paris: Hachette.

Reinecke, John E. 1969. Language and Dialect in Hawaii: Sociolinguistic History to 1935. Honolulu: University of Hawaii.

Reinecke, John F., ct al. 1975. A Bibliography of Pidgin and Creole Languages. 
(Oceanic Linguistics Special Publication, 14). Honolulu: The University Press of Hawaii.

Rémy, (P.) Jules Joseph. n.d. Lettres de P. Rémy, missionnaire apostolique au Congo français. CSE. Dossier III.170- $\Lambda$.

Roeykens, (P.). Auguste. n.d. Une page d'histoire missionnaire de l'Ubangi: le début de l'oeuvre scolaire à Banzyville (1910-1913). Ms. $11 \mathrm{pp}$.

Saint Norbcrt. 1901. Handboekje tot aanleren der taal gebruikt in de Norbertijner Missien van Oewelee. Drukkerij der Abdij van Tongerloo (Belgium).

Samarin, W.J. 1955. Sango, an African lingua franca. Word 11:254-67.

_- 1962. Lingua francas, with special reference to Africa. In Study of the Role of Second Languages, ed. Frank A. Rice, pp. 54-64. Washington, D.C.: Center for $\Lambda$ pplied Linguistics. (Revised, expanded, and reprinted as "Lingua francas of the world", in Readings in the Sociology of Language, ed. Joshua $\Lambda$. Fishman, 1968, pp. 660-72. The Hague: Mouton.)

- 1971a. Salient and substantive pidginization. In Pidginization and Creolization of Languages, ed. Dell Hymes, pp. 117-40. Cambridge University Press.

- $1971 \mathrm{~b}$. Adamawa-Eastern. In Current Trends in Linguistics 7: Linguistics in Sub.Saharan Africa, ed. T.A. Sebeok et al., pp. 213-44. The Hague: Mouton.

- - (with the assistance of Jeanne van Oosten and Walter Brendl). 1975. A twoway dictionary of Bangala and English, based on 'Handboekje tot aanleeren der taal gebruikt in de Norbertijner Missien van Oewelee, 1901'. Unpublished.

- - 1980. Standardization and instrumentalization of creole languages. In The oretical Orientation in Creole Studies, ed. A. Valdman and A. Highfield, pp. 21336, New York: Academic Press.

- Ms. 1. Bondjo ethnicity and colonial imagination. Paper presented at the annual meeting of the Canadian Ethnology Society, 1981.

-.... Ms. 2. The languages of French colonization on the Ubangi river.

Samarin, W.J., and Marcel Diki-Kidiri. 1982. Modernization in Sango. In Language Reform: History and Future, ed. Istvan Fodor and Claude Hagège. Hamburg: H. Buske.

Sankoff, Gillian. 1980. Variation, pidgins and creoles. In Theoretical Orientations in Creole Studies, ed. A. Valdman and A. Highfield, pp. 139-64. New York: Academic Press.

Santandrea, Stefano. 1965. Languages of the Banda and Zande Groups: A Contribution to a Comparative Study. Naples: Istituto Universitario Orientale.

Siepi, J. 1911. Sur quelques moeurs et coutumes des indigènes des régions du HautOubangui et du Haut-Chari. Bull. de la Société de Géographie et d'Études Coloniales de Marseille 35:47-57.

Thomas, Jacqueline M.C. 1963. Le parler Ngbaka de Bokanga: Phonologie, morphologie, syntaxe. The Hague: Mouton.

Thonner, Franz. 1899. Dans la grande forêt de l'Afrique centrale: mon voyage au Congo et à la Mongala en 1896 (translated from German). Brussels: Société Belge de Librairie.

- 1910. Du Congo à l'Ubangi: mon deuxième voyage dans l'Afrique centrale (translated from German). Paris: M. Rivière; Brussels: Misch et Thron.

Tisscrant, Charles. 1931. Dictionnaire banda-français. (Université de Paris, Travaux et Mémoirss, 14). Paris: Institut d'Ethnologie.

Valdman, Albert (ed.) 1977. Pidgin and Creole Linguistics. Bloomington: Indiana University Press.

Van Overbergh, Cyrille, and lid. de Jonghe (eds.) 1907. Les Bangala (État In- 
